\title{
Is green investment different from grey? Return and volatility spillovers between green and grey energy ETFs
}

\author{
Syed Kumail Abbas Rizvi ${ }^{1} \cdot$ Bushra Naqvi $^{1}$ (D) Nawazish Mirza ${ }^{2}$
}

Accepted: 19 October 2021 / Published online: 18 November 2021

(c) The Author(s), under exclusive licence to Springer Science+Business Media, LLC, part of Springer Nature 2021

\begin{abstract}
Investment in Green energy is becoming a popular alternative asset class for investors, primarily due to its environment-friendly attributes. However, there is a dire need for subjective evaluation of this emerging asset class based on the risk-return dynamics to which investors are exposed. To respond to this call, in this study, we conduct this evaluation utilizing a unique and rich data set consisting of daily prices of exchange-traded funds (ETFs) established on different asset classes. We use Vector autoregression and Baba-Engle-Kraft-Kroner parameterization of multivariate GARCH models and assess the relative strength of return and volatility spillovers from the Green and Grey energy markets. Our results reveal the return shocks originated in the Green energy market and transmitted to other markets are more pronounced. It is also observed that the potential to earn high returns and the weak correlation of Green energy ETFs with the traditional asset classes are the crucial factors helpful in inviting attention and investment of investors after 2015. Although our results further suggest that the role of Grey energy is diminishing, as shown by the Impulse response functions and the coefficients of multivariate ARCH and GARCH. Nonetheless, for some asset classes, e.g., Bonds, the volatility spillovers that originated in the Grey energy market are still prominent and robust.
\end{abstract}

Keywords Green energy · Grey energy · Energy derivatives · Exchange-traded funds (ETFs) - Return spillover · Volatility spillover · VAR · BEKK

JEL Classification Q40 · C58 · G11 - G15 · G23

\section{Introduction}

Energy has always been a strategic commodity due to its role in economic development. However, since the early 2000s, energy has gained the reputation of an asset class, and energy-based financial products have become an integral part of the overall financial system.

Bushra Naqvi

bushra.naqvi@lums.edu.pk

1 Lahore University of Management Sciences, Lahore, Pakistan

2 Excelia Business School, La Rochelle, France 
Many studies reason that the financialization of the commodities market and institutional investors' participation has played a vital role in this development (Gagnon et al., 2020). In the financial markets, investors, typically, gain exposure to energy by pursuing investment in energy stocks, energy indices, and energy futures markets through exchange-traded funds (ETFs), exchange-traded notes (ETNs), and swaps, whose returns are tied to an index of energy futures prices (Yan \& Garcia, 2017).

However, the increased participation of investors in commodities markets and the high use of the energy market as an asset class have altered its return and volatility dynamics (Kyritsis \& Serletis, 2018). There has also been an unprecedented increase in the speculative activity in the energy market since 2003 [(Creti \& Nguyen, 2015), (Ahmad, 2017)] coupled with the fact that recent years have witnessed significant volatility in the price of fossil fuel, oil and gas. The volatility in energy prices has also led to the emergence of green energy as a substitute for grey energy. ${ }^{1}$ At the same time, the potential of green energy in combating climate change has also earned international recognition [(Miralles-Quirós et al., 2018), (Su et al., 2020)]. Given these developments, recent years have witnessed a strong interest among practitioners and academics in understanding the dynamics of energy markets. Therefore, this study complements the existing literature and investigates the interdependence and spillovers between grey and green energy markets and traditional financial markets. We argue that an unexpected shift in energy risk and return dynamics could lead to economic instability. Moreover, a financialized energy market may also spread contagion to traditional financial markets like equities and bonds, which are the heart of any financial system.

Spillovers occur when extreme and unexpected shocks in return and volatility in one market trigger volatility in other markets (Engle et al., 1990); and are harsh in markets with greater interdependence, liberalization, and integration [(Rizvi et al., 2013), (Mensi et al., 2013)]. A return spillover captures the return transmission among the financial markets, while volatility spillover is the transmission of volatility (Nguyen \& Le, 2021). High return and volatility spillovers, however, not only indicate the markets' interconnectedness, but those could alter portfolio diversification and hedging strategies [(Mirza et al., 2020); (Li et al., 2021)]. On the one hand, return spillover that originated in one market reflects increased investor confidence in the particular market (Umar et al., 2020); on the other hand, volatility spillovers have implications for the financial system's stability. Nonetheless, they may cause financial contagion, exponentially increases the degree of market systemic risk [(French et al., 1987); (Allen \& Gale, 2000); (Batra, 2002); (Scott, 2011)], and alter investor's decision making by effecting the required rate of returns (Umar et al., 2020) and the cost of capital (Bekaert \& Wu, 2000).

Three strands of literature dominate the literature on return and volatility spillover in the energy market. The first group of studies examines the connection between oil prices and international equity markets [e.g., (Sadorsky, 1999), (Guesmi \& Fattoum, 2014), (Diaz et al., 2016), (Maghyereh et al., 2016), (Zhang, 2017), (Kyritsis \& Serletis, 2018), (Tiwari et al., 2020)]. The second group of studies focus on exploring the relationship between oil price and the stock prices of conventional and green energy [e.g., (Broadstock et al., 2012), (Managi \& Okimoto, 2013), (Wen et al., 2014), (Reboredo et al., 2017), (Reboredo \& Ugolini, 2018)]. In comparison, the third group of studies investigates the association between oil price and the stock prices of conventional, clean energy and the technology companies [e.g., (Henriques \& Sadorsky, 2008), (Sadorsky, 2012a), (Kumar et al., 2012), (Bondia et al., 2016), (Ahmad, 2017), (Ferrer et al., 2018), (Maghyereh et al., 2019), (Elsayed et al., 2020)].

${ }^{1}$ In this study, we use the term Grey energy to refer to fossil fuels and conventional energy while green energy also means renewable energy. 
However, to the best of our knowledge, no study treats grey and green energy as independent asset classes; and examines the connectedness between green and grey energy markets and the interdependence between the pair of the energy market with traditional financial assets markets. The literature has been surprisingly non-focused on the relationship between green energy and equities or bonds despite acknowledging green energy as a rising financial asset with a promising future potential and an asset class alternative to grey energy (Miralles-Quirós \& Miralles-Quirós, 2019). It is also surprising, mainly when there is a parallel literature stream that studies the hedging and diversification benefits of green energy for a stock-bond portfolio [(Bessler \& Wolff, 2015), (Rezec \& Scholtens, 2017), (MirallesQuirós et al., 2018), (Schmidt, 2019), (Henriksen et al., 2019), (Rehman \& Vo, 2020), (Saeed et al., 2020)]. We strongly believe that the evidence on markets' connectedness and spillovers in the green energy market may have important implications for hedging and portfolio diversification, yet the studies explicitly exploring the return and volatility spillover among green energy and traditional asset classes remained missing. This study, therefore, fills this gap in the literature. It enhances the evidence on the linkages among grey, green energy markets, and traditional asset classes. It also examines the presence, nature, and magnitude of the volatility spillovers originated in and transmitted to the energy market or vice versa, which has important implications for the stability of the overall financial system.

We make several contributions to the literature. First, this study provides the first evidence on the green energy market in transmitting return and volatility spillovers to Equities and the Bond market. It contributes to the strand of literature on green energy as well as return and volatility spillovers. Debt has been a significant source of financing in the green market over the years (IRENA, 2020); however, to the best of our knowledge, no study studies the relationship between green energy and the bond market. Second, this study examines the level of connectedness across markets and compares the dominance of green energy to grey energy. Thus, it contributes to the strand of literature assessing the hedging and diversification benefits of green energy for portfolio management. Third, this study uses ETFs to represent all financial markets while the existing literature has been fixated on indices to study the relationship between grey and green energy; or between the grey energy market and the equities market. ETFs are passive investments but are traded like shares and have the potential to track the performance of an index (Miralles-Quirós \& Miralles-Quirós, 2019).

Moreover, investors favor ETFs to gain realized returns instead of non-realizable returns of indices (Yan \& Garcia, 2017). In addition, ETFs have higher liquidity and transparency, lower fees, and tax efficiency (Huang \& Lin, 2011). Fourth, we deploy the most relevant methodology of Baba-Engle-Kraft-Kroner (BEKK) parameterization of multivariate GARCH model ${ }^{2}$ as suggested by (Engle et al., 1995) to capture the spillovers across the financial markets during the time spanning from October 2015 to October 2020.

The fundamental objective of using multivariate GARCH is to extract the time-varying conditional covariance and correlation between the energy market and other financial markets. About GARCH models, it has been widely accepted that Vector error correction (VEC) specifications suggested by (Bollerslev et al., 1988) are arduous to handle while working with more than two variables due to the large number of parameters required. The proposed Diagonal VEC (DVEC) model by (Bollerslev et al., 1988) allows conditional variance but restricts the number of parameters and requires substantial restrictions on the parameters

\footnotetext{
2 To have detailed understanding of GARCH family models, readers are requested to consult the following literature: [(Black, 1976; Christie, 1982); Campbell and Hentschel (1992); Bekaert and Wu (2000); Kroner and $\mathrm{Ng}$ (1998); Glosten, Jagannathan, and Runkle (1993); (Elyasiani et al., 2007); (Chou 1988; Song, Liu, and Romilly 1998; Theodossjiou, Kahya, and Koutmos 1997); (Franses and Van Dijk, 1996; Gokcan, 2000); (Brooks and Persand, 2003).
} 
(Bauwens et al., 2006). Given these constraints, we decided to use BEKK specification proposed by (Engle et al., 1995) and calculate dynamic conditional correlations between the Green and Grey energy markets and other financial markets (Bond and Equity). Moreover, BEKK conveniently decomposes each conditional variance into its ARCH (news impact) and GARCH (persistence) components, simplifying the analysis.

Our results provide interesting insights. We find that the return shocks originated in Green energy and transmitted to grey energy and equities markets are more pronounced. Contrarily, the role of Grey Energy is diminishing, as shown by the Impulse response functions and the coefficients of multivariate ARCH and GARCH. We find a revealing relationship between bond and energy market and show that grey energy significantly affects the BOND market, while the reverse is not valid. However, we find that green energy does not affect bond markets, but the bond market influences the returns of green energy.

The remainder of the paper is structured as follows: Section 2 explains our data set. Section 3 presents the details of the econometric models used to achieve the research objectives. Section 4 presents our empirical results followed by the discussion of results in Sect. 5. Section 6 concludes.

\section{Data}

Our major objective in this paper is to understand and evaluate the dynamics of returns and volatility spillovers that originate in the energy market including Green and the Grey and transmit to other financial markets. To proxy the energy and other assets market we use the rich data set of exchange-traded funds (ETFs) that not only closely track the performance of these markets but are also the tradable financial instruments. This tradability of ETFs make them more realistic choice for any investor interested in taking exposure in the markets of financial assets (Yan \& Garcia, 2017) and (Miralles-Quirós \& Miralles-Quirós, 2019). We choose ETFs for four different markets, Green Energy, Grey Energy, Bond, and Equity, all based in the United State of America (USA). Table 1 below provides the detail of ETFs selected, their representation, coverage and scope.

The ETFs proxies have been selected based on the coverage provided by each index and covers a period of five years of daily frequency starting from October 2015 to October 2020. Adjusted closing prices of ETFs were obtained from Bloomberg and a proxy of monthly returns is calculated for each ETF by taking a natural log of the ratio of current price with the twenty days lagged price on each date available in our data set.

$$
R_{i, t}=\ln \left[\frac{P_{i, t}}{P_{i, t-20}}\right] \times 100
$$

where $R_{i, t}$ is the monthly continuously compounded return calculated for $i$ ETF on day $t$ for each day of sample. $P_{i, t}$ is the daily closing adjusted price for $i$ ETF on day $t$, and $P_{i, t-20}$ represents price for the same ETF 20 days prior. As opposed to the traditional method of calculating monthly returns that relies on calendar-based definition of a month, this method is far superior as it considers each 20 days period as a month on rolling basis. It does not only conform to the real time trading norms where the investors are free to enter or exit the market any day but it also provides higher degree of efficiency making available a larger chunk of data where monthly returns are estimated for each day on rolling basis. This method is also reported to be helpful in curtailing excessive intraday volatility in financial markets (Naqvi et al., 2018). 
Table 1 Asset classes in the portfolios. Source: Bloomberg

\begin{tabular}{|c|c|c|c|}
\hline Asset Class & Proxy Index & Geo-Focus & Coverage \\
\hline Green energy & $\begin{array}{l}\text { First Trust NASDAQ } \\
\text { Clean Edge Green } \\
\text { Energy Index Fund } \\
(\text { QCLN) }\end{array}$ & USA & $\begin{array}{l}\text { The fund tracks the price and yield of } \\
\text { an equity index called the NASDAQ } \\
\text { Clean Edge Green Energy Index. The } \\
\text { index tracks the performance of } \\
\text { publicly traded clean energy } \\
\text { companies in the United States. The } \\
\text { fund invests at least } 90 \% \text { of its net } \\
\text { assets in the common stocks and } \\
\text { depositary receipts that comprise the } \\
\text { index }\end{array}$ \\
\hline Grey energy & $\begin{array}{l}\text { Energy Select Sector } \\
\text { SPDR Fund (XLE) }\end{array}$ & USA & $\begin{array}{l}\text { The fund corresponds generally to the } \\
\text { price and yield performance of } \\
\text { publicly traded equity securities of } \\
\text { companies in the Energy Select } \\
\text { Sector Index. The index holds stocks } \\
\text { of companies from oil, gas, } \\
\text { consumable fuels, energy equipment } \\
\text { and services' industries. The fund } \\
\text { generally invests } 95 \% \text { of its total } \\
\text { assets in the stocks comprising the } \\
\text { index }\end{array}$ \\
\hline Bond (BOND) & $\begin{array}{l}\text { iShares Core U.S. } \\
\text { Aggregate Bond ETF } \\
\text { (AGG) }\end{array}$ & USA & $\begin{array}{l}\text { The fund tracks the performance of the } \\
\text { Bloomberg Barclays U.S. Aggregate } \\
\text { Bond Index which itself measures the } \\
\text { performance of the total U.S. } \\
\text { investment-grade bond market. The } \\
\text { fund invests generally at least } 90 \% \text { of } \\
\text { its net assets in component securities } \\
\text { of the underlying index; while } \\
\text { remaining \% is invested in the } \\
\text { securities with substantially identical } \\
\text { economic characteristics }\end{array}$ \\
\hline Equity (EQUITY) & $\begin{array}{l}\text { SPDR S\&P } 500 \text { ETF } \\
\text { Trust (SPY) }\end{array}$ & USA & $\begin{array}{l}\text { The investment corresponds to the } \\
\text { yield and price performance of the } \\
S \& P 500 \text { Index. The ETF is the } \\
\text { portfolio of the common stocks that } \\
\text { are included in the index; and the } \\
\text { weight of each stock in the Portfolio } \\
\text { corresponds to the weight of such } \\
\text { stock in the index }\end{array}$ \\
\hline Risk free rate & $\begin{array}{l}\text { US } 3 \text { Months Treasury } \\
\text { Bill Yield }\end{array}$ & USA & Short Term Treasury Bills \\
\hline
\end{tabular}


Figure 1 shows trends in the daily ETF prices of selected asset classes during the last five years (October 2015-October 2020). Equity ETF has been measured on secondary axis (right side) and rest of the ETFs are measured on primary axis (left side). The Grey energy market seems to exhibit a long-term declining trend since 2017, almost the same time when the Green Energy market has started climbing, albeit slowly. Interestingly, both the decline of Grey and the climb of Green energy markets seem to be exacerbated by the COVID-19 pandemic in early 2020.

The equity market exhibits a trend like Grey market and indicates a strong correlation between the two financial markets. However, a widening of gap in prices over the years could also be observed. The bond market, contrarily, exhibits a relatively less volatile price trend and quite resembles the trends in green energy market.

\section{Models}

\subsection{Return spillovers}

We begin our preliminary investigation about the existence of spillovers in excess returns, across time, and between different segments of asset classes, by estimating vector autoregressive model (VAR) for the excess returns of four asset classes i.e. Green Energy (GREEN), Grey Energy (GREY), Bond (BOND) and Equity (EQUITY) in the following manner;

$$
\boldsymbol{E} \boldsymbol{R}_{t}=\varnothing_{0}+\varnothing_{1} \boldsymbol{E} \boldsymbol{R}_{t-1}+\cdots+\varnothing_{\mathbf{p}} \boldsymbol{E} \boldsymbol{R}_{t-\mathbf{p}}+\varepsilon_{\boldsymbol{t}}\left(\varepsilon_{t} \mid \psi(t-1) \sim N\left(0, H_{t}\right)\right)
$$

where $\boldsymbol{E} \boldsymbol{R}_{\boldsymbol{t}}$ is a four variable vector demonstrating excess returns in the four ETFs (GREEN, GREY, BOND, EQUITY) at time period $t ; p$ is the optimal lag length identified through $\mathrm{AIC}$ and BIC; $\varnothing_{0}$ is a $4 \times 1$ vector representing intercepts; $\varnothing_{1}$ through $\varnothing_{\mathbf{p}}$ are coefficient matrices, with their elements capturing their own, as well as the cross-market lag effects; and $\varepsilon_{t}$ is a $4 \times 1$ vector of residual error terms. Our assumption is that the elements of $\varepsilon_{t}$ are not serially correlated, with the conditional variance-covariance matrix represented by the $4 \times$ 4 matrix $H_{t}$ given the information set $\psi(t-1)$.

Equation (2) specifies that the excess return of each ETF is a linear function of lagged excess returns of the same as well as lagged returns of the ETF of the other market segments. For example, the excess return in the Green Energy Market (GREEN) depends on $p$ lags of itself, as well as $p$ lags of the other three ETF's excess returns:

$$
\begin{aligned}
& \boldsymbol{E}_{1, \boldsymbol{t}}=\varnothing_{0}+\sum_{i=1}^{p} \varnothing_{1 i} \boldsymbol{E} \boldsymbol{R}_{1, \boldsymbol{t}-\mathbf{i}}+\sum_{i=1}^{p} \varnothing_{2 i} \\
& \boldsymbol{E}_{2, \boldsymbol{t}-\mathbf{i}}+\sum_{i=1}^{p} \varnothing_{3 i} \boldsymbol{E} \boldsymbol{R}_{3, \boldsymbol{t}-\mathbf{i}}+\sum_{i=1}^{p} \varnothing_{4 i} \boldsymbol{E} \boldsymbol{R}_{4, \boldsymbol{t}-\mathbf{i}}+\varepsilon_{1, \boldsymbol{t}} \\
& \boldsymbol{E}_{2, \boldsymbol{t}}=\boldsymbol{\beta}_{0}+\sum_{i=1}^{p} \boldsymbol{\beta}_{1 i} \boldsymbol{E} \boldsymbol{R}_{1, \boldsymbol{t}-\mathbf{i}}+\sum_{i=1}^{p} \boldsymbol{\beta}_{2 i} \boldsymbol{E} \boldsymbol{R}_{2, \boldsymbol{t}-\mathbf{i}}+\sum_{i=1}^{p} \boldsymbol{\beta}_{3 i} \boldsymbol{E} \boldsymbol{R}_{3, \boldsymbol{t}-\mathbf{i}}+\sum_{i=1}^{p} \boldsymbol{\beta}_{4 i} \boldsymbol{E} \boldsymbol{R}_{4, \boldsymbol{t}-\mathbf{i}}+\varepsilon_{2, \boldsymbol{t}} \\
& \quad \boldsymbol{E} \boldsymbol{R}_{\boldsymbol{n}, \boldsymbol{t}}=\ldots \ldots \ldots \ldots \ldots \ldots \ldots \ldots \ldots \ldots \ldots \ldots \ldots \ldots \ldots \ldots \ldots \ldots \ldots \ldots \ldots \ldots \ldots \ldots \ldots \ldots \ldots \ldots \ldots \ldots \ldots \ldots \ldots \ldots \ldots \ldots \ldots
\end{aligned}
$$

The presence of excess return spillovers from the ETF of equity market, EQUITY(4) towards green energy market, GREEN(1) can be detected by validating the joint hypothesis that $\varnothing_{4 i}=0(i=1, \ldots, p)$ and alternatively to detect the spillovers from GREEN towards 
other markets ETFs, equations similar to Eq. 3 can be developed for each ETF's excess returns having its own lagged excess returns as well as the lagged excess returns of other ETFs.

\subsection{Volatility spillovers and volatility persistence}

The second type of spillovers are volatility spillovers where return shocks (difference between actual and mean or expected returns) in one market on a given day, trigger the conditional variance or volatility next day, either in the same market or in some other market (Rizvi \& Naqvi, 2008; Rizvi et al., 2014). Similarly, persistence in the volatility of one market can be spilled over next day towards the other markets. The overall concept may be called as temporal dependence of the conditional variance.

We propose in this paper to use Baba, Engle, Kraft and Kroner (BEKK) parameterization of multivariate GARCH model $^{3}$ as suggested by (Engle et al., 1995) to estimate the volatility spillovers, volatility persistence and volatility transmissions from GREY and GREEN energy markets to other financial markets and vice versa.

The basic objective to use multivariate GARCH was to extract the time varying conditional covariance and correlation between energy market and other financial markets. With reference to GARCH models, it has been widely accepted that vector error correction (VEC) specifications suggested by (Bollerslev et al., 1988) are extremely difficult to handle while working with more than two variables due to the large number of parameters required $\left[\frac{N(N+1)(N(N+1)+1)}{2}=210\right.$ for $\left.N=4\right]$. (Bollerslev et al., 1988) proposed Diagonal VEC (DVEC) model which allows conditional variance depending only on its own lag and on the lagged values of cross product of errors $\left(\boldsymbol{\epsilon}_{i t} \boldsymbol{\epsilon}_{j t}\right)$ thus restricting the number of parameters up to $\left[\frac{N(N+5)}{2}=18\right.$ for $\left.N=4\right]$. Nonetheless even in diagonal VEC representation it is extremely difficult to ensure the positivity of conditional variance covariance matrix $\left(H_{t}\right)$ unless we impose strong restrictions on the parameters (Bauwens et al., 2006). Keeping in view these constraints we decide to use BEKK specification proposed by (Engle et al., 1995) to calculate dynamic conditional correlations between Green/Grey energy markets and other financial markets: Bond and Equity. We assume that $\psi(t-1)$ is the information field generated by the past values of $\epsilon_{t}$ and that $H_{t}$ is the conditional variance-covariance matrix of the k-dimensional random vector $\epsilon_{t}$. We also assume that $H_{t}$ is measurable with respect to past information set $\psi(t-1)$; in that case the structure of multivariate $\mathrm{G}_{p} \mathrm{ARCH}$ would be as

$$
\left(\epsilon_{t} \mid \psi(t-1) \sim N\left(0, H_{t}\right)\right) H_{t}=C+\sum_{i=1} A_{i}^{\prime} \epsilon_{t-i} \epsilon_{t-i}^{\prime} A_{i}+\sum_{i=1} G_{i}^{\prime} H_{t-i} G_{i}
$$

where $C, A_{i}$ and $G_{i}$ are $k \times k$ parameter matrices.

For bivariate $\operatorname{GARCH}(1,1)$ the matrix structure would be as follows.

$$
\begin{aligned}
H_{t}= & {\left[\begin{array}{ll}
c_{11} & c_{12} \\
c_{12} & c_{22}
\end{array}\right]+\left[\begin{array}{ll}
a_{11} & a_{12} \\
a_{21} & a_{22}
\end{array}\right]^{\prime}\left[\begin{array}{cc}
\epsilon_{1, t-1}^{2} & \epsilon_{1, t-1} \in_{2, t-1} \\
\epsilon_{2, t-1} \in_{1, t-1} & \epsilon_{2, t-1}^{2}
\end{array}\right]\left[\begin{array}{ll}
a_{11} & a_{12} \\
a_{21} & a_{22}
\end{array}\right] } \\
& +\left[\begin{array}{ll}
g_{11} & g_{12} \\
g_{21} & g_{22}
\end{array}\right]^{\prime} H_{t-1}\left[\begin{array}{ll}
g_{11} & g_{12} \\
g_{21} & g_{22}
\end{array}\right]
\end{aligned}
$$

\footnotetext{
3 To have detailed understanding of GARCH family models, readers are requested to consult the following literature: [(Black, 1976; Christie, 1982); Campbell and Hentschel (1992); Bekaert and Wu (2000); Kroner and Ng (1998); Glosten, Jagannathan, and Runkle (1993); (Elyasiani et al., 2007); (Chou 1988; Song, Liu, and Romilly, 1998; Theodossjiou, Kahya, and Koutmos, 1997); (Franses and Van Dijk, 1996; Gokcan, 2000); (Brooks and Persand, 2003).
} 
We maximize the following log-likelihood function for our Multivariate GARCH model, written without a constant term;

$$
\uparrow=-\frac{1}{2} \sum_{t=1}^{T}\left[\log \left|H_{t}\right|+\epsilon_{t}^{\prime} H_{t}^{-1} \epsilon_{t}\right]
$$

We use the continuously compounder returns calculated through Eq. 1 and estimate excess returns (ER) by subtracting period adjusted risk free rate, for the construction of mean equation which would be modelled as Vector Auto regression (VAR) as specified in Eq. 3;

The superiority of BEKK model is that it conveniently decomposes each conditional variance into its $\mathrm{ARCH}$ (news impact) and $\mathrm{GARCH}$ (persistence) components. For example, the $\mathrm{ARCH}$ component which is the impact of lagged squared residuals in excess returns associated with the conditional variance of Green energy ETFs (GREEN) can be represented as:

$$
\begin{aligned}
\boldsymbol{H}_{(i . i), t}= & \boldsymbol{c}_{11}+\boldsymbol{a}_{11}^{2} \in_{1, t-1}^{2}+\boldsymbol{a}_{21}^{2} \in_{2, t-1}^{2}+\boldsymbol{a}_{31}^{2} \in_{3, t-1}^{2}+\boldsymbol{a}_{41}^{2} \in_{4, t-1}^{2}+2 \boldsymbol{a}_{11} \boldsymbol{a}_{21} \in_{1, t-1} \in 2, t-1 \\
& +2 \boldsymbol{a}_{11} \boldsymbol{a}_{31} \in_{1, t-1} \in_{3, t-1}+2 \boldsymbol{a}_{11} \boldsymbol{a}_{41} \in_{1, t-1} \in_{4, t-1}+2 \boldsymbol{a}_{21} \boldsymbol{a}_{31} \in_{2, t-1} \in_{3, t-1} \\
& +2 \boldsymbol{a}_{21} \boldsymbol{a}_{41} \in_{2, t-1} \in_{4, t-1}+2 \boldsymbol{a}_{31} \boldsymbol{a}_{41} \in_{3, t-1} \in_{4, t-1}
\end{aligned}
$$

In the above structure, 1, 2, 3, and 4are respectively the representation of GREEN, GREY, BOND and EQUITY ETFs. The structure clearly shows that ARCH volatility of GREEN excess returns not only depends on the lagged squared residuals (shocks) in all ETF markets, but on the cross-products of the lagged shocks in all four ETF markets. Here the ARCH coefficients, $\boldsymbol{a}_{11}, \boldsymbol{a}_{21}, \boldsymbol{a}_{31}$, and $\boldsymbol{a}_{41}$ capture the effects of past squared residuals (shocks) in excess returns of each market's ETF on today' volatility in green energy ETFs excess returns.

Alternatively, the persistence parameter or GARCH component of the green energy ETF's conditional variance can be decomposed as,

$$
\begin{aligned}
\boldsymbol{H}_{(i . i), t}= & \boldsymbol{g}_{11}^{2} \boldsymbol{H}_{11, t-1}+\boldsymbol{g}_{21}^{2} \boldsymbol{H}_{22, t-1}+\boldsymbol{g}_{31}^{2} \boldsymbol{H}_{33, t-1}+\boldsymbol{g}_{41}^{2} \boldsymbol{H}_{44, t-1}+2 \boldsymbol{g}_{11} \boldsymbol{g}_{21} \boldsymbol{H}_{12, t-1} \\
& +2 \boldsymbol{g}_{11} \boldsymbol{g}_{31} \boldsymbol{H}_{13, t-1}+2 \boldsymbol{g}_{11} \boldsymbol{g}_{41} \boldsymbol{H}_{14, t-1}+2 \boldsymbol{g}_{21} \boldsymbol{g}_{31} \boldsymbol{H}_{23, t-1}+2 \boldsymbol{g}_{21} \boldsymbol{g}_{41} \boldsymbol{H}_{24, t-1} \\
& +2 \boldsymbol{g}_{31} \boldsymbol{g}_{41} \boldsymbol{H}_{34, t-1}
\end{aligned}
$$

where the volatility of GREEN excess returns is a function of past conditional variances in all four markets and the covariance structure associated with each of the four markets. Here, $\boldsymbol{g}_{11}, \boldsymbol{g}_{21}, \boldsymbol{g}_{31}$, and $\boldsymbol{g}_{41}$ capture the effects of past volatility (own conditional variance) in each market's ETF on today' volatility in GREEN excess returns.

\subsection{Rationale to choose BEKK model}

It is extremely important that we should justify our choice of using BEKK model in this study. Since it has been explained earlier that research objective of this study is to distinguish the spillover effect of Grey and Green energy to and from other financial markets based on historical data and not the forecasting of returns. Therefore, the BEKK-GARCH is much sounder, owing to its high number of parameters compared to the DCC-GARCH (Huang et al., 2010).

It is true that full BEKK model has its shortcomings such as "curse of dimensionality" but so is the case with the alternative model such as DCC. Such shortcomings of DCC-GARCH are clearly highlighted by (Chang, McAleer, and Wang, 2018a, 2018b) who preclude the usage of multivariate DCC-GARCH on the basis of its "lack of regularity conditions and 
hence no statistical conditions" while supporting their argument citing the working paper by (Hafner and McAleer 2014). In fact if we look at not-so-distant past work of McAleer, not only it has supported BEKK (Caporin and Mcaleer 2012) but also used it extensively as well (Allen et al., 2017; Asai, Gupta, and McAleer 2020).

As a solution, the three most comprehensive works on the shortcomings of full BEKK and DCC, strongly recommend and use the Diagonal BEKK instead of full BEKK or DCC. All these studies confirm that the Quasi Maximum Liklihood Estimates (QMLE) of the parameters in Diagonal BEKK only, have both the asymptotic properties of consistency as well as asymptotic normality (Chang et al., 2018a, 2018b, 2019b).

However, as we have explained earlier that our objective is to estimate the spillovers running between Green/Grey Energy market and the other financial markets (Bond and Equity) which can only be captured through off-diagonal terms in ARCH and GARCH matrices and can only be estimated through full BEKK model. Therefore, estimating diagonal BEKK or DCC, both of which can only produce diagonal terms of ARCH and GARCH matrices or the partial covolatility spillovers, will add no value at all in our study (Chang et al., 2018a).

This is exactly the reason why (Chang et al., 2019a) despite their heavy criticism on full BEKK specifications, failed to estimate these parameters which we present in this paper and which they termed as full volatility and full covolatility spillovers. They also admitted full BEKK model as the "HOLY GRAIL" for the estimation of spillovers in totality. Moreover, This is precisely why two of the recent and comprehensive papers by (Li, 2015; Sarwar et al., 2020) have used the full BEKK specifications that also support our initial stance of relying on the same.

Even the (Sadorsky, 2012b) despite choosing DCC as first choice, admitted candidly that BEKK is not only the closest second choice but it also produces more evidences of volatility spillovers than does the DCC model. Similarly (Sadorsky, 2014) highlighted in foot notes the possibility of using several other specifications than DCC, including BEKK.

To summarize above, given the most important consideration of this paper is to evaluate cross market spillovers running two and from energy markets (Green and Grey) which can only be estimated through off-diagonal coefficients of $\mathrm{ARCH}$ and GARCH matrices, we do not have any other choice but to follow the lead of leading researchers by employing full BEKK. (Allen et al., 2017; Chang et al., 2019a; Gulzar et al., 2019; Huang et al., 2010; Li, 2015; Rizvi \& Itani, 2021; Sadorsky, 2012a; Sarwar et al., 2019, 2020; Wang et al., 2019; Yousaf et al., 2021).

\section{Results}

\subsection{Descriptive statistics}

In this section we first present the descriptive statistics and correlations of the excess returns calculated for the ETFs representing four markets in Tables 2 and 3 respectively.

The descriptive statistics provided in Table 2 strongly reinforce our quest of examining the volatility dynamics in Green and Grey Energy markets and their spillovers towards other financial markets. In terms of returns, both Green and Grey energy markets are prominent as GREEN offers the most lucrative monthly average returns of $1.6 \%$ and GREY offers the worst returns equals to the negative $0.96 \%$ as monthly average. Both GREY and GREEN energy markets are highest in terms of risks with a standard deviation of $9.8 \%$ and $8.1 \%$ per 
Table 2 Descriptive Statistics of Monthly Excess Returns (\%)

\begin{tabular}{lllll}
\hline & Green & Grey & Bond & Equity \\
\hline Mean & 1.6037 & 0.9673 & 0.2320 & 0.8731 \\
Median & 1.9687 & 0.1591 & 0.2239 & 1.5387 \\
Maximum & 26.979 & 31.8971 & 9.8768 & 20.7545 \\
Minimum & 58.9087 & 82.7384 & 6.8930 & 37.0844 \\
Std. Dev & 8.1341 & 9.8618 & 1.0506 & 4.9473 \\
Skewness & 1.7633 & 2.9950 & 0.8309 & 2.5054 \\
Kurtosis & 14.0692 & 22.0826 & 15.2020 & 18.6606 \\
Jarque-Bera & 6978.79 & $20,684.83$ & 7841.67 & $13,980.07$ \\
Probability & 0.0000 & 0.0000 & 0.0000 & 0.0000 \\
Sum & 1990.25 & 1200.50 & 287.95 & 1083.55 \\
Sum Sq. Dev & $82,042.93$ & $120,596.60$ & 1368.73 & $30,350.57$ \\
Observations & 1241 & 1241 & 1241 & 1241
\end{tabular}

The table shows the descriptive statistics of the monthly returns of ETFs in four selected markets. The values are the percentages (\%) wherever applicable

\begin{tabular}{|c|c|c|c|c|}
\hline & Green & Grey & Bond & Equity \\
\hline \multirow[t]{2}{*}{ Green } & 1.0000 & & & \\
\hline & - & & & \\
\hline \multirow[t]{2}{*}{ Grey } & 0.2960 & 1.0000 & & \\
\hline & 0.0000 & - & & \\
\hline \multirow[t]{2}{*}{ Bond } & 0.0466 & 0.1105 & 1.0000 & \\
\hline & 0.0137 & 0.0000 & - & \\
\hline \multirow[t]{2}{*}{ Equity } & 0.5906 & 0.4966 & 0.0348 & 1.0000 \\
\hline & 0.0000 & 0.0000 & 0.0662 & - \\
\hline
\end{tabular}

The table shows the pairwise Kendall rank correlation coefficients (tau-a) between the monthly returns of four markets. The correlation coefficient ranges between -1 to 1 . The correlation values are followed by the p-values
Table 3 Correlation (Kendall Tau) among Monthly Excess Returns $(\%)$ in Different ETFs

month respectively. In terms of returns skewness, other than BOND which has a positive skewness owing to its principal protection feature, the GREEN market has the lowest value of negative skewness offering better returns prospects. In terms of fat tail risk all markets have excess kurtosis indicating higher probability of extreme shocks. Besides, we find that the correlation coefficients of both Green and Grey energy markets with Bond and Equity are reasonably low and even negative sometimes (see Table 3) which is consistent with the literature arguing for the diversification potential of energy markets. Graphical representation of correlations structure is provided in Scatterplot matrix in Fig. 2.

\subsection{Preliminary evaluation of unit root and stationarity}

To ensure that the chosen series is appropriate for the implementation of full BEKK model, it is important that the series should be stationary and free from unit root. Foreseeing the potential issue of cointegration or non-stationarity, not only we base our entire analysis on 
continuously compounder returns (log returns) but to further isolate the individual series from the global and common trends and to focus on the true and intrinsic relationship only between chosen series, we further synthesize our variables and convert them into Excess Returns by subtracting the US Tbills rate of return as a proxy of global risk free rate as all our original series were denominated in USD. This subtraction of US T bills rate minimizes the impact of systematic events that are reflected in the movement of US Tbills rate and are capable to affect different financial markets simultaneously. We therefore have already laid down the foundations to ensure that the series included in our data set are eligible for the application of chosen econometric analysis as it is highly unlikely to find unit root in such synthesized series. However, to ensure the stationarity of data we test all series for the potential Unit root, Unit root with Break and for possible Cointegration between GREEN, GREY, BOND and EQUITY returns. The results are reported in Fig. 3 and Tables 6, 7 and 8. For all return series $\mathrm{ADF}$ and PP test is rejected thus refuting the presence of unit root. Results also fail to reject the null of KPSS thus confirming that the series are stationary. Similarly, ADF Unit root with Break test also reject the presence of unit root confirming the stationarity of data. Finally no evidence of cointegration is found based on Trace and Max Eigen Statistics of Johansen's cointegration test.

\subsection{Return spillover}

Table 4 presents the results of Vector auto regression model where excess return in each ETF segment (each column) is explained by the two periods lagged excess returns in the same as well as in the other three markets. The lag length selection criteria is applied and based on the optimal AIC and BIC two period lag has been chosen for the VAR specification. The results of lag length selection criteria are reported in Table 9. Moreover, the graphical description of impulse responses of different markets and variance decomposition tables have also been provided in Fig. 4 and Table 10 respectively.

In Table 4 above if we focus on GREEN(-1) and GREEN(-2) which are the lagged coefficients of excess returns in Green energy market we would observe clearly that the past excess return shocks in Green market have a potential to impact current excess returns in GREY and EQUITY markets besides impacting its own excess returns today. This finding is also corroborated by the variance decomposition reported in Table 10 and can be visualized in the Impulse reponse functions provided in Fig. 4. Table 10 shows that the shocks in GREEN energy market are responsible for around $42 \%$ to $49 \%$ of the variations in GREY market, $66 \%$ to $70 \%$ of the variation in EQUITY market and $97 \%$ to $100 \%$ of the variation in the GREEN market itself. Interestingly the bond market (BOND) is completely immune to the return shocks originated in green energy market, however the reverse is not true as the Green energy market is getting affected by the return shocks in the Bond market. Again if we look at the variance decomposition, the percentage contribution of GREEN market in BOND market's variance is merely $1 \%$ at most. Exactly opposite to this phenomenon and linkages observed for the GREEN market, the return shocks in GREY market are only able to impact the Bond market besides impacting itself but the GREY market in turn is immune to the shocks originated in Bond market. Infact the share of GREY market in the variance of BOND market is around $1.5 \%$ to $3.5 \%$ percent. Finally, the equity market (EQUITY) has some impact on all markets except BOND. However the variance decomposition and the impulse response functions reported in Fig. 4 indicate clealry its weaker influence and less pronounced dominance within these markets. On the other hand and indeed surprisingly, the much greater influence and dominance is shown by the Green energy market which is 
Table 4 Vector Autoregressive (VAR) Estimates

\begin{tabular}{|c|c|c|c|c|}
\hline & Green & Grey & Bond & Equity \\
\hline \multirow[t]{3}{*}{ Green $(-1)$} & 1.1539 & 0.2006 & 0.0045 & 0.1614 \\
\hline & $(0.0495)$ & $(0.0544)$ & $(0.0082)$ & $(0.0333)$ \\
\hline & {$[23.2758]$} & [3.6824] & [0.5477] & [4.8448] \\
\hline \multirow[t]{3}{*}{ Green $(-2)$} & -0.2440 & -0.2708 & -0.0013 & -0.1773 \\
\hline & $(0.0495)$ & $(0.0544)$ & $(0.0082)$ & $(0.0333)$ \\
\hline & {$[-4.9229]$} & {$[-4.9721]$} & {$[-0.1670]$} & {$[-5.3217]$} \\
\hline \multirow[t]{3}{*}{ Grey $(-1)$} & -0.0280 & 0.9646 & 0.0208 & 0.0139 \\
\hline & $(0.0419)$ & $(0.0460)$ & $(0.0070)$ & $(0.0281)$ \\
\hline & {$[-0.6680]$} & [20.9447] & [ 2.9679] & [0.4936] \\
\hline \multirow[t]{3}{*}{ Grey $(-2)$} & 0.0355 & 0.0007 & -0.0180 & 0.0136 \\
\hline & $(0.0419)$ & $(0.0460)$ & $(0.0070)$ & $(0.0281)$ \\
\hline & [0.8482] & {$[0.0170]$} & {$[-2.5736]$} & [0.4843] \\
\hline \multirow[t]{3}{*}{ Bond $(-1)$} & 0.6946 & 0.2700 & 1.0041 & 0.1738 \\
\hline & $(0.1701)$ & $(0.1869)$ & $(0.0284)$ & $(0.1143)$ \\
\hline & [ 4.0832] & [1.4448] & [35.2855] & [1.5203] \\
\hline \multirow[t]{3}{*}{ Bond $(-2)$} & -0.5843 & -0.2036 & -0.0957 & -0.0649 \\
\hline & $(0.1704)$ & $(0.1873)$ & $(0.0285)$ & $(0.1145)$ \\
\hline & {$[-3.4279]$} & {$[-1.0873]$} & {$[-3.3583]$} & {$[-0.5672]$} \\
\hline \multirow[t]{3}{*}{ Equity $(-1)$} & -0.3911 & -0.4838 & -0.0131 & 0.5059 \\
\hline & $(0.0823)$ & $(0.0905)$ & $(0.0137)$ & $(0.0553)$ \\
\hline & {$[-4.7479]$} & {$[-5.3441]$} & {$[-0.9552]$} & [9.1374] \\
\hline \multirow[t]{3}{*}{ Equity $(-2)$} & 0.4495 & 0.5682 & 0.0036 & 0.4132 \\
\hline & $(0.0822)$ & $(0.0903)$ & $(0.0137)$ & $(0.0552)$ \\
\hline & [5.4649] & {$[6.2870]$} & [ 0.2620$]$ & [7.4760] \\
\hline R-squared & 0.9094 & 0.9255 & 0.8477 & 0.8890 \\
\hline Adj. R-squared & 0.9089 & 0.9251 & 0.8468 & 0.8884 \\
\hline
\end{tabular}

The table shows the VAR estimates for four markets. Each market's monthly returns in VAR are assumed to be the function of its own lagged returns (autoregressive) as well as the lagged returns of other three markets. The values of t-statistics are shown in brackets [] and p-values are shown in parenthesis ()

nonetheless perceived as a new and less prominent market segment compared to EQUITY. This behavior and dominance of GREEN is also interesting when we compare it with the GREY market which traditionally has been influencing major financial markets owing to the intrinsic economic importance of Oil, Gas and other fossil fuel energy products.

\subsection{Volatility spillover and volatility persistence}

Finally, Table 5 presents the estimated coefficients, standard errors (squared brackets) and t-statistics (bold) of $\mathrm{ARCH}^{4}$ and GARCH represented in Eqs. 6 and 7. The oversized diagonal terms are own ARCH and own GARCH effect for all four markets. The full BEKK model is

4 To confirm the presence of ARCH effects, we conducted ARCH LM test for all excess returns series of GREEN, GREY, BOND and EQUITY ETFs and found significant presence of ARCH effects in all series 
Table 5 Estimated ARCH and GARCH coefficients in BEKK Model

\begin{tabular}{|c|c|c|c|c|}
\hline Parameters & $\operatorname{GREEN}(., 1)$ & $\operatorname{GREY}(., 2)$ & $\operatorname{BOND}(., 3)$ & $\operatorname{EQUITY}(., 4)$ \\
\hline \multicolumn{5}{|c|}{ ARCH Coefficients } \\
\hline \multirow[t]{3}{*}{$\mathbf{A}(1,)}$. & 1.189430 & 0.657219 & 0.021262 & 0.962439 \\
\hline & {$[0.033410]$} & {$[0.028170]$} & {$[0.014363]$} & {$[0.051930]$} \\
\hline & 35.601285 & 23.330719 & -1.480262 & 18.533473 \\
\hline \multirow[t]{3}{*}{$A(2,)}$. & 0.561067 & 0.410274 & 0.460343 & 0.200531 \\
\hline & {$[0.354725]$} & [0.028016] & [0.086433] & [0.136999] \\
\hline & 1.581698 & 14.644343 & 5.326005 & 1.463745 \\
\hline \multirow[t]{3}{*}{$\mathbf{A}(3,)}$. & 0.204550 & 0.080655 & 0.952529 & 0.265629 \\
\hline & [0.043509] & {$[0.018527]$} & {$[0.055875]$} & {$[0.115371]$} \\
\hline & 4.701302 & 4.353353 & 17.047601 & 2.302378 \\
\hline \multirow[t]{3}{*}{$\mathbf{A}(4,)}$. & 0.963223 & 0.813633 & -0.528070 & 2.073095 \\
\hline & {$[0.169774]$} & {$[0.053967]$} & {$[0.151024]$} & {$[0.098148]$} \\
\hline & 5.673569 & 15.076608 & 3.496585 & 21.122064 \\
\hline Parameters & GREEN(., 1) & $\operatorname{GREY}(., 2)$ & $\operatorname{BOND}(., 3)$ & EQUITY(., 4) \\
\hline \multicolumn{5}{|c|}{ GARCH Coefficients } \\
\hline \multirow[t]{3}{*}{$\mathbf{G}(1,)}$. & 0.523681 & 0.011634 & 0.004799 & 0.094553 \\
\hline & {$[0.084544]$} & {$[0.009768]$} & {$[0.005746]$} & {$[0.097550]$} \\
\hline & 6.194175 & 1.191025 & 0.835092 & 0.969280 \\
\hline \multirow[t]{3}{*}{$\mathbf{G}(2,)}$. & 0.169109 & 0.742943 & 0.058581 & 0.795973 \\
\hline & {$[0.165252]$} & [0.022209] & {$[0.008321]$} & [0.137279] \\
\hline & 1.023337 & 33.452222 & 7.040276 & 5.798222 \\
\hline \multirow[t]{3}{*}{$\mathbf{G}(3,)}$. & 4.533144 & 0.204812 & 0.119789 & 4.639357 \\
\hline & [0.949515] & [0.155328] & [0.029987] & [1.178895] \\
\hline & 4.774168 & 1.318575 & 3.994697 & 3.935342 \\
\hline \multirow[t]{3}{*}{$G(4,)}$. & 0.149024 & 0.762695 & 0.076811 & 1.676974 \\
\hline & [0.248317] & [0.273459] & {$[0.015415]$} & {$[0.082514]$} \\
\hline & 0.600133 & 2.789061 & 4.982980 & 20.323544 \\
\hline
\end{tabular}

The table shows the estimated ARCH and GARCH coefficients, standard errors (squared brackets) and tstatistics (bold) estimated through Eqs. 6 and 7. The terms $\mathrm{A}(n,$.$) and \mathrm{G}(n,$.$) in first column shows the ARCH$ and GARCH spillovers originated in $\boldsymbol{n t h}$ market and runs through the markets given in column 2 to 5

estimated using RATS 10.0. The default algorithm to optimize the log-liklihood estimation function in RATS is BHHH (Berndt, Hall, Hall and Hausman) by (Berndt et al., 1974). However we also used the alternative optimization algorithm of BFGS (Broyden, Fletcher, Goldfarb and Shanno) by (Broyden, 1965, 1967; Fletcher \& Powell, 1963) for robustness purposes. Both these algorithms are Hill climbing algorithms and our results are robust and are not subject to change by the change of algorithm. Similarly, for the choice of underlying distribution, although the results reported below are according to student's t distribution,

Footnote 4 continued

based on the LM test statistics $(T-q) R^{2}$ which was greater than $\chi_{(1-a, q)}^{2}$ thus rejecting the null hypothesis of No ARCH effects. 
but they are robust to the usage of GED (generalized exponential distribution) the other alternative available in RATS 10.0.

The estimated coefficients to capture ARCH effects exhibit some interesting patterns. First, all oversized diagonal elements $\mathrm{A}(1,1), \mathrm{A}(2,2), \mathrm{A}(3,3)$ and $\mathrm{A}(4,4)$ are highly statistically significant based on the t-statistic below (in bold). This suggests that the conditional variances in each of the four market segments depend on their own lagged squared residuals. The equity market (EQUITY) has the largest own ARCH effect with the coefficient value of 2.073, while the grey energy (GREY) has the smallest own ARCH effect with the value of 0.410 . The own ARCH effect in green energy market (GREEN) is largest after EQUITY with an approximate value of 1.189. If we focus on the row $\mathrm{A}(1,$.$) which tells us the impact of shock in green$ energy market (GREEN) on other market segments, the t-value is significantly greater than 2.0 for all three markets except BOND. This indicates the strong effect and news impact on volatility in all markets except BOND if there is any shock in green energy market. The same is not true for the row $\mathrm{A}(2$, . $)$ which captures the similar impact of shocks originated in GREY market. The shock in GREY market is only able to increase its own conditional variance and the conditional variance in BOND market. This is the identical behavior that we explored in case of return spillovers estimated through VAR in Table 4. The volatility transmission from the other two markets, Bond and Equity is significant and visible indicating the dominance of both markets in global financial system.

The persistence or GARCH parameters G(., i) in the lower half of Table 5 capture the responses of conditional variance (volatility) in market $i$ to past conditional variance (volatility) in each of the four markets. To understand the volatility spillovers from green energy market (GREEN) to other markets we need to focus on estimated coefficients provided in row $\mathrm{G}(1$, .). The Conditional variance in no market seem to be responsive towards the volatility spillover originated in GREEN market, other than the GREEN market itself. Put differently, the transfer of volatility persistence spillovers from GREEN market to other market is weak and insignificant. On the contrary the grey market (GREY) through parameter $G(2$, .) seems to transfer significant volatility shocks towards BOND and EQUITY if the turbulence in grey market persists. This observation is interesting as we find previously ( $\mathrm{ARCH}$ and VAR) that GREEN market appears to be more prominent than GREY market in spilling over return shocks and news impact-based volatility shocks. However, the situation is reverse for the persistence-based volatility shocks and the GREY market still acts as a dominant market with the capability to shake the other markets if the volatility shocks persists in it. There is a mixed pattern in the transmission of volatility persistence spillovers from BOND and EQUITY to other markets with an interesting result that the equity market (EQUITY) despite being dominant otherwise, is unable to spillover its GARCH based volatility towards green energy market.

For the interested readers the estimated conditional standard deviation, conditional correlation and conditional variance covariance structures for the data are also reported in Figs. 5, 6 and 7 respectively.

\section{Discussion}

The findings show that Green energy has emerged as the prominent player in determining the returns of the equity market while the role of Grey is exhibiting diminishing trend. Our findings are different from the earlier studies that claimed that grey energy in the form of oil price changes are an important factor affecting stock market returns [(Sadorsky, 1999), 
(Park \& Ratti, 2008), (El-Sharif et al., 2005), (Guesmi \& Fattoum, 2014), (Diaz et al., 2016), (Maghyereh et al., 2016)]. However, Our results are supported by recent studies which report skepticism on the role of conventional energy in explaining stock markets returns [(Zhang, 2017), (Kyritsis \& Serletis, 2018), (Elsayed et al., 2020), (Tiwari et al., 2020)]. Contrarily, our findings on green energy are novel and non-comparable to the existing strand of literature and show that the relationship is bi-directional where green energy affects the returns of stock market while equities affects the returns of green energy.

Our results are interesting and also hints towards the increased financialization of energy markets (Ferrer et al., 2018) as they show that equities explain the changes in the returns of grey and green energy market. Earlier literature assumed energy price changes as an exogenous factor which was a reasonable assumption but only before the financialization of energy market. Now, energy market has deep presence in the financial market in the form of energy future, swaps, ETN and ETFs which exhibit characteristics that are like those of other financial assets (Zhang, 2017). Moreover, energy has itself become a financial asset with its price reacting to and influencing other assets in financial markets (Kyritsis \& Serletis, 2018); and is used increasingly by portfolio managers and institutions to hedge and diversify their portfolios [(Bessler \& Wolff, 2015), (Rehman et al., 2019), (Gagnon et al., 2020)]. In addition, (Creti \& Nguyen, 2015) and (Ahmad, 2017) argue for an unprecedented increase in the speculative activities in the energy market after 2003; which also means that energy market and oil prices are no longer independent from the changes in financial markets.

Our results are also revealing for the relationship of green and grey energy with the bond market which has largely been overlooked by the literature. We show that grey energy is having a significant effect on bond market, while the reverse is not true. Intrigued about the reasoning of this interesting result, it was also very surprising for us to note that although there exists a rich literature studying the relationship between oil and equities, the same is not true for the relationship between oil and bond market. However, an extended literature does examine the relationship between oil prices and interest rates motivated by the fact that both variables have always increased prior to US postwar recession [(Hamilton, 1983), (Hamilton, 1996), (Bernanke et al., 1997), (Bernanke et al., 2004)]; and hence provides plausible rationale and support to our results that grey energy affects bond market via interest rate transmission channel. While we show that Grey energy market affects bond market, we find that green energy does not affect bond market. Instead, it is being significantly affected by the Bond Market. One plausible explanation of this unidirectional return spillovers is that most of the investment in Green energy is channeled through Bond market. Green energy projects are capital intensive and of long-term maturity; and debt represents a major source of financing for such projects (IRENA, 2020). Our results therefore have meanings since any turbulence in the overall bond market or changing yield spread could impact the financing and investment in Green energy projects and their returns subsequently. 
While comparing our results of relationship between grey and green energy, however, our results are consistent with those of [(Henriques \& Sadorsky, 2008), (Reboredo et al., 2017), (Ferrer et al., 2018), (Elsayed et al., 2020)] who show that there is a limited or no role of oil prices in effecting the prices of green energy. Besides, we find that green energy has taken the leader's position where the changes in the prices of green energy are affecting the returns of grey energy.

However, although the return spillovers (VAR) and news-based volatility spillovers (ARCH) from Green Energy to other markets are prominent but that's not true for Volatility Persistence Spillovers (GARCH). This could be explained by the fact that Grey energy market still dominates the energy market with the total share of around $84 \%$ (Ferrer et al., 2018) and persistence in volatility of grey energy (fossil fuel) still has the potential to threaten monetary and financial stability.

\section{Conclusion}

This research provides evidence on the connectedness of grey and green energy as independent asset classes with other financial assets and markets and reports results on the presence of return and volatility spillovers that may originate in energy market and are transmitted to the other major financial markets.

Our study is inspired by several recent developments in the energy market. Firstly, energy has earned the status of a financial asset class while still retaining its status of a strategic commodity. Secondly, the financialization of energy market has led to an unprecedented increase in the speculative and hedging activities in the energy based financial products. Thirdly, the prices of energy have become extremely volatile in recent years which may cause not only economic instability but also trigger the contagion in the financial markets. Lastly, a move towards sustainable economic development that has gained momentum around the world and consequently the role of green energy is strengthening as a substitute or an alternative of conventional grey energy not only as a commodity but as a financial asset too.

The study is, however, different from the existing literature because we emphasize on the relationship between green and grey energy and the spillover to and from pair of energy markets to equities-bonds markets. Earlier literature has either been focused on oil, fossil fuel or the conventional energy market and their relationship with the equities market; or the returnvolatility relationships between conventional (grey) energy with green energy and technology companies' stocks and it does not view green energy as an alternative asset class. The fact however is that the green energy is a rising asset class as well as an alternative investment to grey energy with promising growth potential; and the evidence on green market connectedness and spillovers have important implications for hedging and portfolio diversification too; but yet the studies explicitly exploring green energy as an independent asset class remained missing; and therefore this study makes a significant contribution to the literature on green energy return and volatility spillover.

The results provide evidence on the diminishing role of Grey energy and the prominent role of Green Energy in Equity market return dynamics. First, we show that Green energy is more prominent in determining the returns of equity market while the role of Grey energy in US equity market is declining. Second, we find that equities explain the changes in the returns of both grey and green energy market and thus hints towards the increasing financialization of Green energy too. Third, while comparing our results of relationship between grey and green energy, we find that green energy again proves itself more important as it could guide the prices in grey energy market whereas the reverse is not true. However, although the return 
spillovers (VAR) and news-based volatility spillovers (ARCH) from Green Energy to other markets are prominent but that's not true for Volatility Persistence Spillovers (GARCH). This is explainable as Grey energy market still dominates the energy market with the total share of around $84 \%$.

The findings of this study have important implications for investors, portfolio managers and the overall financial system. Green energy has emerged as an independent asset class and a strong alternative to grey energy and hence have the potential to alter the investors' decision making and asset selection and allocation. The green energy also seems to take the leading role in energy segment and affect investors' sentiments as the confidence of investors in green energy is spilled over in the other financial markets. Our results also provide important insights for regulators and policy makers as the energy today enjoys the dual status. Energy has retained its status of a strategic commodity while it has also become an integral part of the financial system. Green energy, which is envisioned to provide a solution to climate change and to the volatile prices of grey energy, has become closely connected with equities and bonds as suggested by our results. Therefore, a larger financial oversight of green energy market by the regulators, just like other financial markets, is inevitable owing to its increased connectedness with the different segments of the financial system. This increased Financialization of green energy coupled with the strong interest of investors in it as an asset class also expose green energy to speculative activities which may make the prices of green energy volatile too. Moreover, any turbulence in the overall equities and bond market or changing yield spread could impact the Green energy investments hence impeding the world's efforts to achieve sustainable development goals.

\section{Appendix}

See Tables 6, 7, 8, 9, 10 and Figs. 1,2, 3, 4, 5, 6, 73. 
Table 6 Unit Root and Stationarity Testing (Excess Returns of GREEN, GREY, BOND and ENERGY market Returns)

\begin{tabular}{|c|c|c|c|c|c|c|}
\hline \multirow[t]{3}{*}{ Variables } & \multicolumn{2}{|l|}{$\mathrm{ADF}$} & \multicolumn{2}{|l|}{ PP } & \multicolumn{2}{|l|}{ KPSS } \\
\hline & \multicolumn{2}{|c|}{ Null: Series has a unit root } & \multicolumn{2}{|c|}{ Null: Series has a unit root } & \multicolumn{2}{|c|}{$\begin{array}{l}\text { Null: Series is } \\
\text { stationary }\end{array}$} \\
\hline & Intercept & $\begin{array}{l}\text { Intercept and } \\
\text { Trend }\end{array}$ & Intercept & $\begin{array}{l}\text { Intercept and } \\
\text { Trend }\end{array}$ & Intercept & $\begin{array}{l}\text { Intercept } \\
\text { and Trend }\end{array}$ \\
\hline GREEN & - $4.3986^{* * * *}$ & $-4.6299 * * *$ & $-5.5473^{* * * *}$ & $-5.6891 * * *$ & 0.2934 & 0.0970 \\
\hline GREY & - $4.4681^{* * *}$ & $-4.5989 * * *$ & $-5.4169^{* * * *}$ & $-5.4941 * * *$ & 0.2343 & 0.0365 \\
\hline BOND & $-{ }^{-} 4.7562 * * *$ & $-4.8122 * * *$ & ${ }^{-} 7.5242^{* * * *}$ & $-7.6131 * * *$ & $0.4298 *$ & $0.1414 *$ \\
\hline \multirow[t]{2}{*}{ EQUITY } & $-5.2546^{* * * *}$ & $-5.2553 * * *$ & $-{ }_{5.9866^{* * * *}}$ & $-5.9843 * * *$ & 0.0266 & 0.0269 \\
\hline & $\mathrm{ADF}$ & PP & KPSS & & & \\
\hline $\begin{array}{l}\text { Test Critical } \\
\text { Values }\end{array}$ & Intercept & $\begin{array}{l}\text { Intercept and } \\
\text { Trend }\end{array}$ & Intercept & $\begin{array}{l}\text { Intercept and } \\
\text { Trend }\end{array}$ & Intercept & $\begin{array}{l}\text { Intercept } \\
\text { and Trend }\end{array}$ \\
\hline $1 \%$ level & $-_{3.435497}$ & -3.965586 & $-_{3.435411}$ & -3.965464 & 0.739000 & 0.216000 \\
\hline $5 \%$ level & ${ }^{-} 2.863700$ & -3.413499 & $-^{-} .863662$ & -3.413440 & 0.463000 & 0.146000 \\
\hline $10 \%$ level & $-{ }^{-} .567970$ & -3.128795 & $-{ }^{-} .567950$ & -3.128760 & 0.347000 & 0.119000 \\
\hline
\end{tabular}

$* * *, * *$ and $*$ denote statistical significance at $0.01,0.05$ and 0.10 levels, respectively

Table 7 Augmented Dickey-Fuller "Unit Root with Break" test Results

\begin{tabular}{|c|c|c|c|}
\hline Variables & & Break Date & t-Statistic \\
\hline GREEN & & $4 / 01 / 2020$ & $-6.417479 * * *$ \\
\hline GREY & & $3 / 18 / 2020$ & $-5.150519 * * *$ \\
\hline BOND & & $11 / 08 / 2018$ & $-5.332880 * * *$ \\
\hline EQUITY & & $3 / 20 / 2020$ & $-6.045231 * * *$ \\
\hline \multirow[t]{3}{*}{ Test critical values: } & $1 \%$ level & & -4.945706 \\
\hline & $5 \%$ level & & -4.432140 \\
\hline & $10 \%$ level & & -4.182082 \\
\hline
\end{tabular}


Table 8 Johansen's System Cointegration Test

Sample (adjusted): 11/05/2015 10/02/2020

Included observations: 1236 after adjustments

Trend assumption: Linear deterministic trend

Series: GREEN GREY BOND EQUITY

Lags interval (in first differences): 1 to 4

\begin{tabular}{lllll}
\hline $\begin{array}{l}\text { Unrestricted Cointegration Rank Test (Trace) } \\
\text { Hypothesized }\end{array}$ & & & & \\
No. of CE(s) & Eigenvalue & Statistic & Critical Value & Prob.** \\
\hline None * & 0.061495 & 209.6665 & 47.85613 & 0.0000 \\
At most $1 *$ & 0.051931 & 131.2218 & 29.79707 & 0.0000 \\
At most $2 *$ & 0.033001 & 65.30776 & 15.49471 & 0.0000 \\
$\begin{array}{l}\text { At most } 3 * \\
\text { Trace test indicates } 4 \text { cointegrating eqn(s) at } \\
\text { the 0.05 level }\end{array}$ & 0.019095 & 23.82967 & 3.841466 & 0.0000 \\
$*$ denotes rejection of the hypothesis at the & & & & \\
$\begin{array}{l}\text { 0.05 level } \\
* * \text { MacKinnon-Haug-Michelis (1999) p-values }\end{array}$ & & & & \\
\hline
\end{tabular}

Unrestricted Cointegration Rank Test

(Maximum Eigenvalue)

\begin{tabular}{|c|c|c|c|c|}
\hline \multirow{2}{*}{$\begin{array}{l}\text { Hypothesized } \\
\text { No. of CE(s) }\end{array}$} & \multirow[b]{2}{*}{ Eigenvalue } & \multirow{2}{*}{$\begin{array}{l}\text { Max-Eigen } \\
\text { Statistic }\end{array}$} & \multicolumn{2}{|l|}{0.05} \\
\hline & & & Critical Value & Prob.** \\
\hline None * & 0.061495 & 78.44476 & 27.58434 & 0.0000 \\
\hline At most $1 *$ & 0.051931 & 65.91401 & 21.13162 & 0.0000 \\
\hline At most $2 *$ & 0.033001 & 41.47810 & 14.26460 & 0.0000 \\
\hline At most $3 *$ & 0.019095 & 23.82967 & 3.841466 & 0.0000 \\
\hline \multicolumn{5}{|l|}{$\begin{array}{l}\text { Max-eigenvalue test indicates } 4 \\
\text { cointegrating eqn(s) at the } 0.05 \text { level }\end{array}$} \\
\hline \multicolumn{5}{|l|}{$\begin{array}{l}* \text { denotes rejection of the hypothesis at } \\
\text { the } 0.05 \text { level }\end{array}$} \\
\hline $\begin{array}{l}\text { **MacKinnon-Haug-Michelis (1999) } \\
\text { p-values }\end{array}$ & & & & \\
\hline
\end{tabular}

\begin{tabular}{llll}
$\begin{array}{l}\text { Unrestricted Cointegrating } \\
\text { Coefficients (normalized by } \\
\left.\mathrm{b}^{*} \mathrm{~S} 11 * \mathrm{~b}=\mathrm{I}\right) \text { : }\end{array}$ & & \\
Green & Grey & Bond & Equity \\
\hline-0.005983 & 0.007802 & -0.858018 & -0.096607 \\
0.247486 & 0.164768 & -0.186329 & -0.627852 \\
0.059478 & -0.080105 & -0.619702 & 0.233127 \\
0.125809 & -0.132376 & 0.136346 & -0.043107 \\
\hline
\end{tabular}


Table 9 Lag Length Selection Criteria

Endogenous variables: ER_GREEN ER_GREY ER_BOND ER_EQUITY

Exogenous variables: $\mathrm{C}$

Sample: 10/01/2015 10/02/2020

Included observations: 1233

\begin{tabular}{lll}
\hline Lag & AIC & SC (BIC) \\
0 & 20.54107 & 20.55767 \\
1 & 12.44482 & 12.52782 \\
2 & $12.44433^{*}$ & $12.43374 *$ \\
3 & 12.45855 & 12.44436 \\
4 & 12.46566 & 12.44788 \\
5 & 12.51421 & 12.46282 \\
6 & 12.68250 & 12.49752 \\
7 & 12.67011 & 12.53154 \\
8 & 12.74824 & 12.49607 \\
\hline
\end{tabular}

Table 10 Variance Decomposition

\begin{tabular}{|c|c|c|c|c|c|}
\hline Period & S.E & GREEN & GREY & BOND & EQUITY \\
\hline \multicolumn{6}{|c|}{ Variance Decomposition of GREEN: } \\
\hline 1 & 2.456218 & 100.0000 & 0.000000 & 0.000000 & 0.000000 \\
\hline 2 & 3.396743 & 97.82012 & 0.478303 & 0.779389 & 0.922190 \\
\hline 3 & 4.101321 & 97.53893 & 0.405874 & 1.264791 & 0.790409 \\
\hline 4 & 4.638263 & 97.44410 & 0.345879 & 1.510385 & 0.699631 \\
\hline 5 & 5.071938 & 97.44545 & 0.292693 & 1.657588 & 0.604272 \\
\hline 6 & 5.430215 & 97.45981 & 0.255778 & 1.755243 & 0.529171 \\
\hline 7 & 5.732162 & 97.45974 & 0.237416 & 1.827023 & 0.475824 \\
\hline 8 & 5.989963 & 97.43358 & 0.238776 & 1.884128 & 0.443515 \\
\hline 9 & 6.212334 & 97.37691 & 0.260411 & 1.932497 & 0.430181 \\
\hline 10 & 6.405670 & 97.28891 & 0.302386 & 1.975398 & 0.433309 \\
\hline \multicolumn{6}{|c|}{ Variance Decomposition of GREY: } \\
\hline 1 & 2.699016 & 49.01595 & 50.98405 & 0.000000 & 0.000000 \\
\hline 2 & 3.597946 & 49.39526 & 49.21527 & 0.132070 & 1.257404 \\
\hline 3 & 4.308043 & 49.20008 & 49.49228 & 0.240401 & 1.067241 \\
\hline 4 & 4.861836 & 48.50200 & 50.30864 & 0.278637 & 0.910724 \\
\hline 5 & 5.323832 & 47.60962 & 51.33298 & 0.291065 & 0.766334 \\
\hline 6 & 5.717836 & 46.61245 & 52.42978 & 0.291949 & 0.665821 \\
\hline 7 & 6.061402 & 45.56064 & 53.54096 & 0.288278 & 0.610122 \\
\hline 8 & 6.365353 & 44.48406 & 54.63826 & 0.282991 & 0.594684 \\
\hline 9 & 6.637417 & 43.40241 & 55.70681 & 0.277456 & 0.613328 \\
\hline 10 & 6.883157 & 42.32955 & 56.73866 & 0.272286 & 0.659503 \\
\hline
\end{tabular}


Table 10 (continued)

\begin{tabular}{|c|c|c|c|c|c|}
\hline Period & S.E & GREEN & GREY & BOND & EQUITY \\
\hline \multicolumn{6}{|c|}{ Variance Decomposition of BOND: } \\
\hline 1 & 0.410889 & 0.047193 & 1.513040 & 98.43977 & 0.000000 \\
\hline 2 & 0.588046 & 0.552049 & 2.758699 & 96.65440 & 0.034852 \\
\hline 3 & 0.703589 & 0.682140 & 3.129770 & 96.05267 & 0.135420 \\
\hline 4 & 0.785450 & 0.757373 & 3.306698 & 95.73043 & 0.205496 \\
\hline 5 & 0.845728 & 0.802895 & 3.386530 & 95.53816 & 0.272418 \\
\hline 6 & 0.891278 & 0.834863 & 3.423876 & 95.40679 & 0.334472 \\
\hline 7 & 0.926253 & 0.858333 & 3.438510 & 95.30956 & 0.393601 \\
\hline 8 & 0.953395 & 0.876223 & 3.440880 & 95.23313 & 0.449769 \\
\hline 9 & 0.974611 & 0.890086 & 3.436406 & 95.17055 & 0.502956 \\
\hline 10 & 0.991276 & 0.900916 & 3.428235 & 95.11785 & 0.552997 \\
\hline \multicolumn{6}{|c|}{ Variance Decomposition of EQUITY: } \\
\hline 1 & 1.650696 & 66.01381 & 8.400665 & 0.066857 & 25.51866 \\
\hline 2 & 2.051994 & 71.98577 & 7.172741 & 0.100904 & 20.74059 \\
\hline 3 & 2.413953 & 73.19192 & 7.314578 & 0.252401 & 19.24110 \\
\hline 4 & 2.690775 & 73.66278 & 7.703963 & 0.396401 & 18.23685 \\
\hline 5 & 2.923541 & 73.55386 & 8.272292 & 0.542374 & 17.63147 \\
\hline 6 & 3.120551 & 73.18652 & 8.927916 & 0.685526 & 17.20004 \\
\hline 7 & 3.290762 & 72.65097 & 9.644044 & 0.825454 & 16.87953 \\
\hline 8 & 3.439407 & 72.01145 & 10.40036 & 0.960803 & 16.62739 \\
\hline 9 & 3.570478 & 71.30316 & 11.18469 & 1.090521 & 16.42163 \\
\hline 10 & 3.686917 & 70.55006 & 11.98789 & 1.213713 & 16.24833 \\
\hline
\end{tabular}

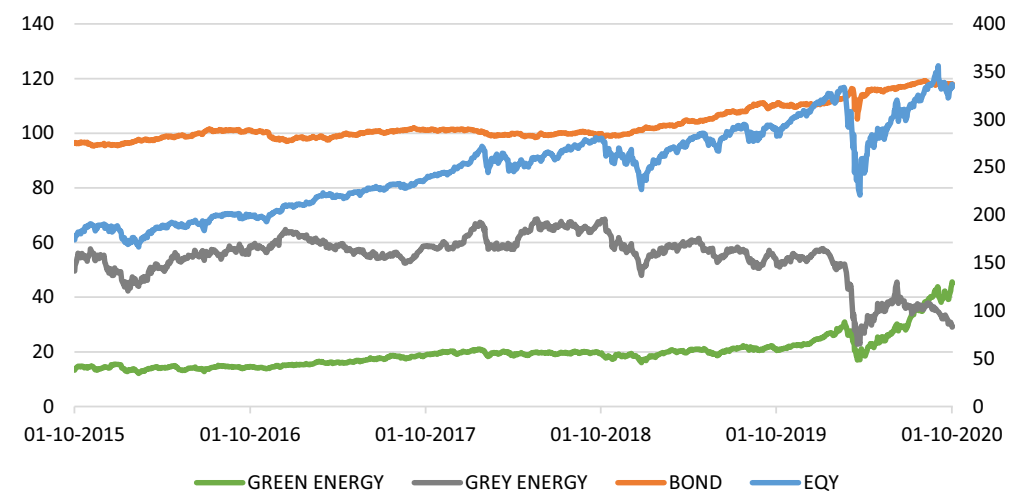

Fig. 1 Prices of ETFs of Selected Asset Classes. Note: Green Energy, Grey Energy and Bond ETFs' prices are measured on primary axis and Equity ETF's price is measured on secondary axis. The data spans from October 2015 to October 2020 


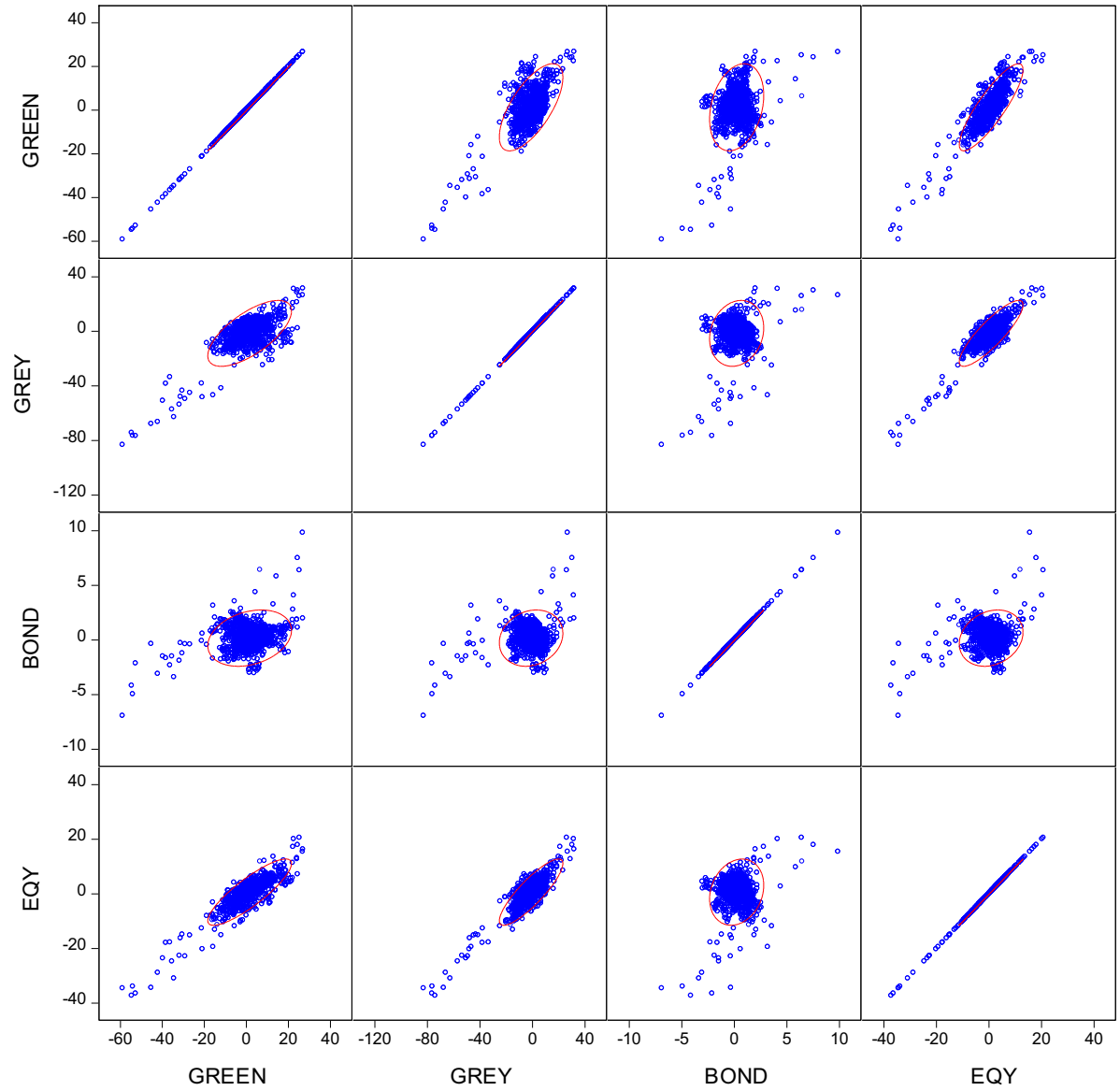

Fig. 2 Scatterplot Matrix 


\section{(A) ADF “Unit Root with Break" Statistics: GREEN Energy}
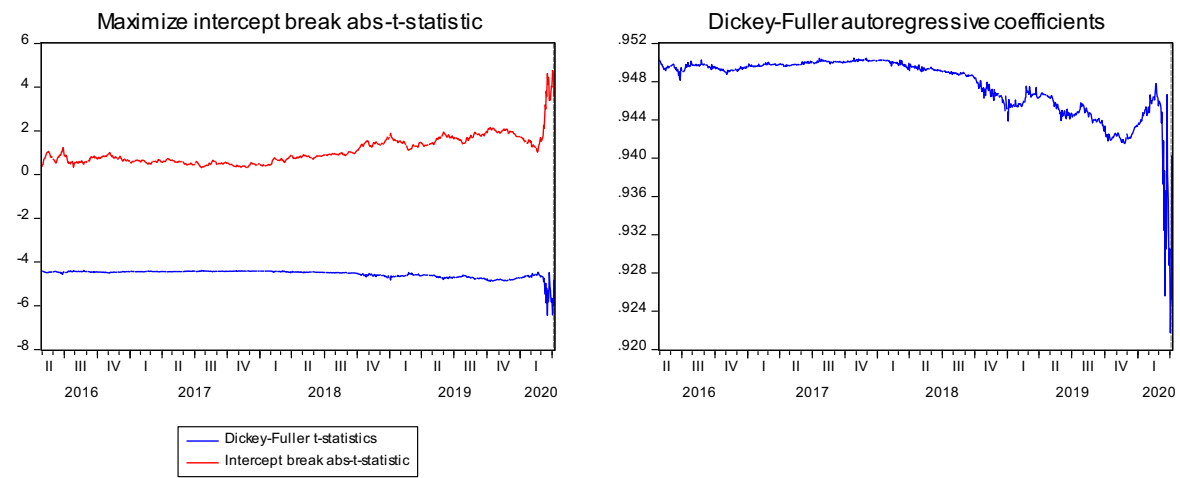

\section{(B) ADF "Unit Root with Break" Statistics: GREY Energy}
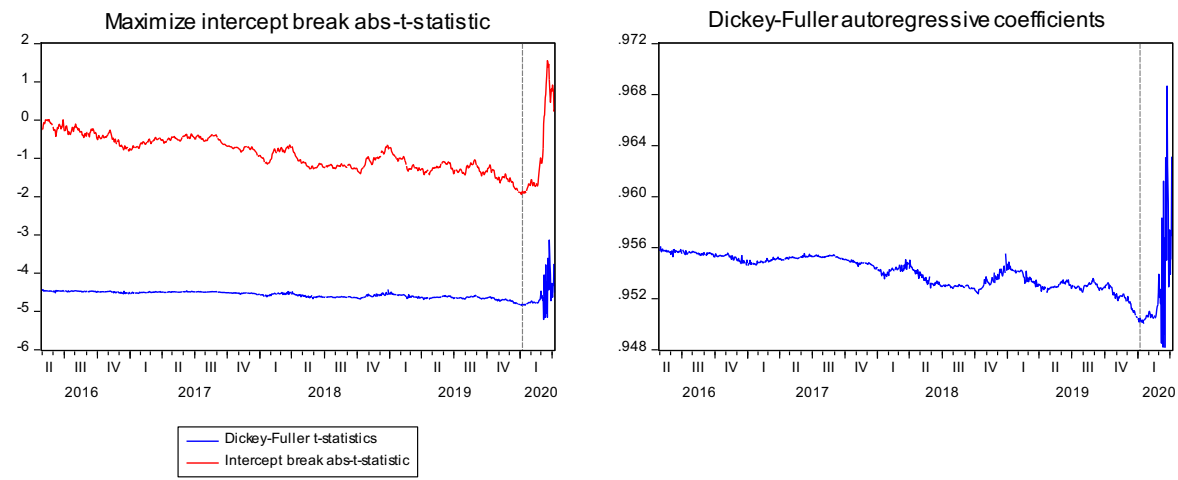

\section{(C) ADF "Unit Root with Break" Statistics: BOND}
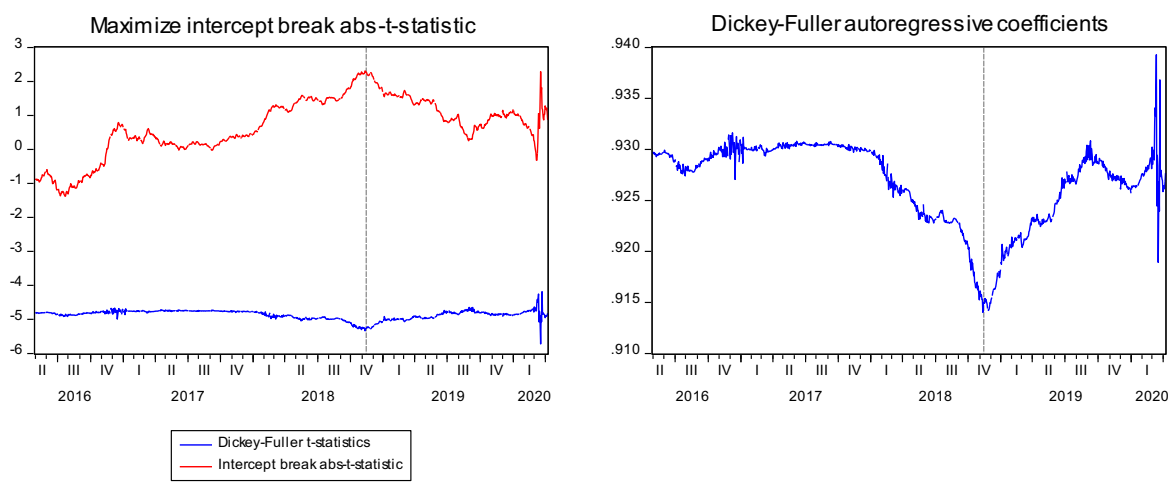

Fig. 3 Augmented Dickey-Fuller "Unit Root with Break" test Results. a: ADF "Unit Root with Break" Statistics: GREEN Energy. b: ADF "Unit Root with Break" Statistics: GREY Energy. c: ADF "Unit Root with Break" Statistics: BOND. d: ADF "Unit Root with Break" Statistics: EQUITY 


\section{(D) ADF “Unit Root with Break" Statistics: EQUITY}
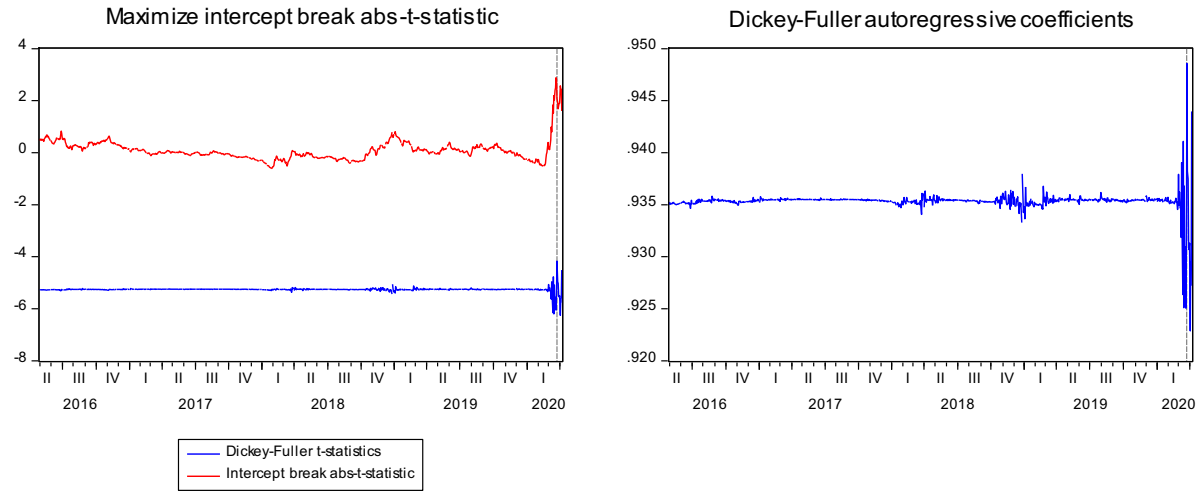

Fig. 3 continued

\section{Response to Cholesky One S.D. (d.f. adjusted) Innovations}
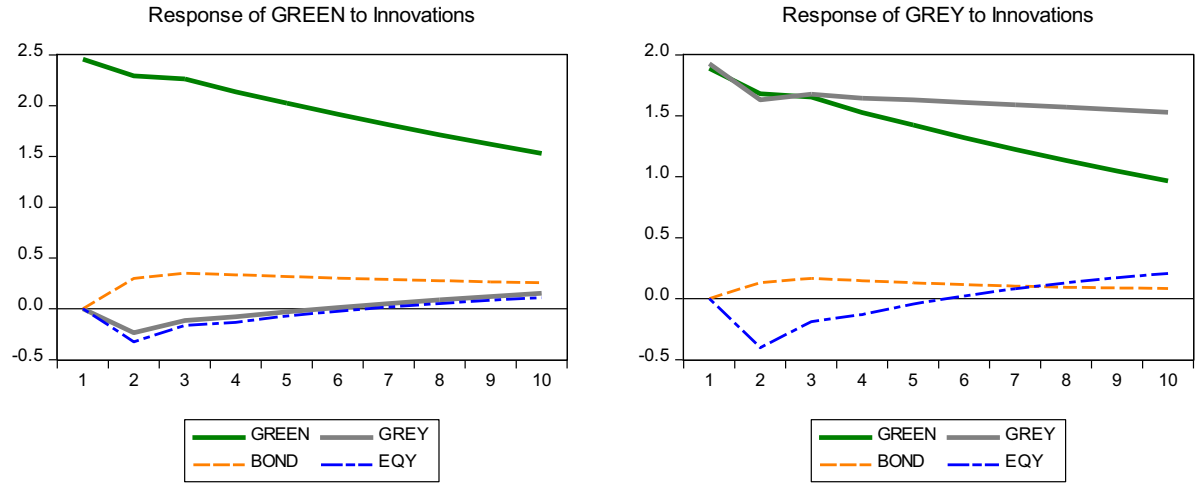

Response of BOND to Innovations

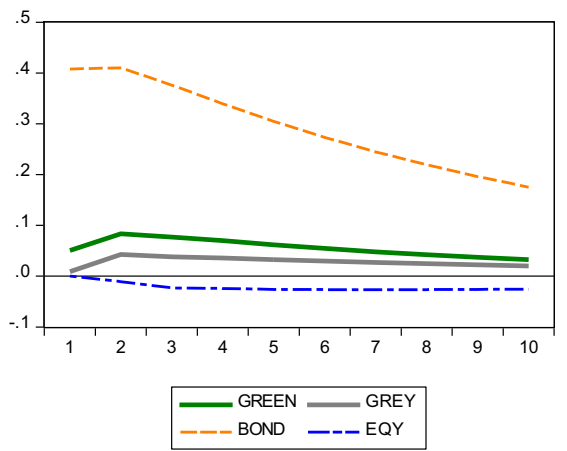

Response of EQY to Innovations

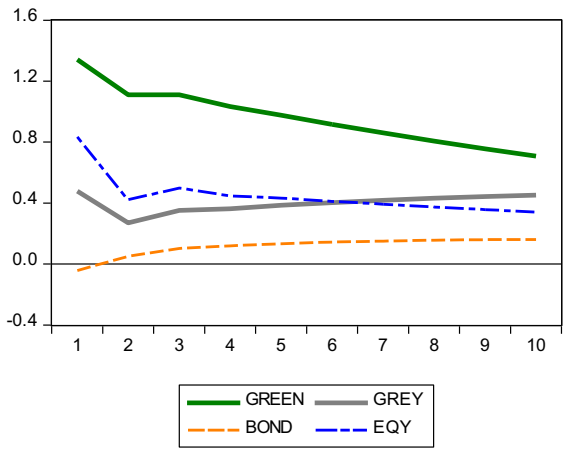

Fig. 4 Impulse response functions 


\section{Conditional Standard Deviation}

Std( Green)
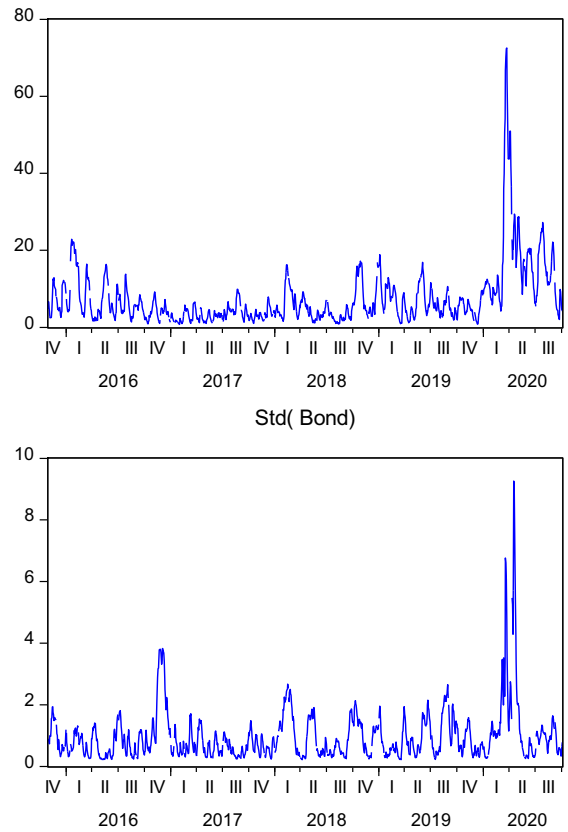

Std( Grey)
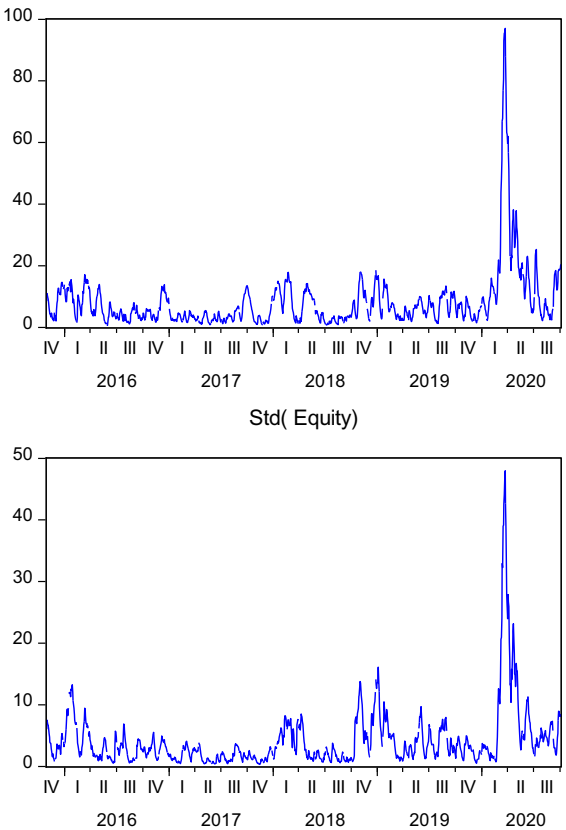

Fig. 5 Conditional standard deviations in excess returns (\%)

Conditional Correlation
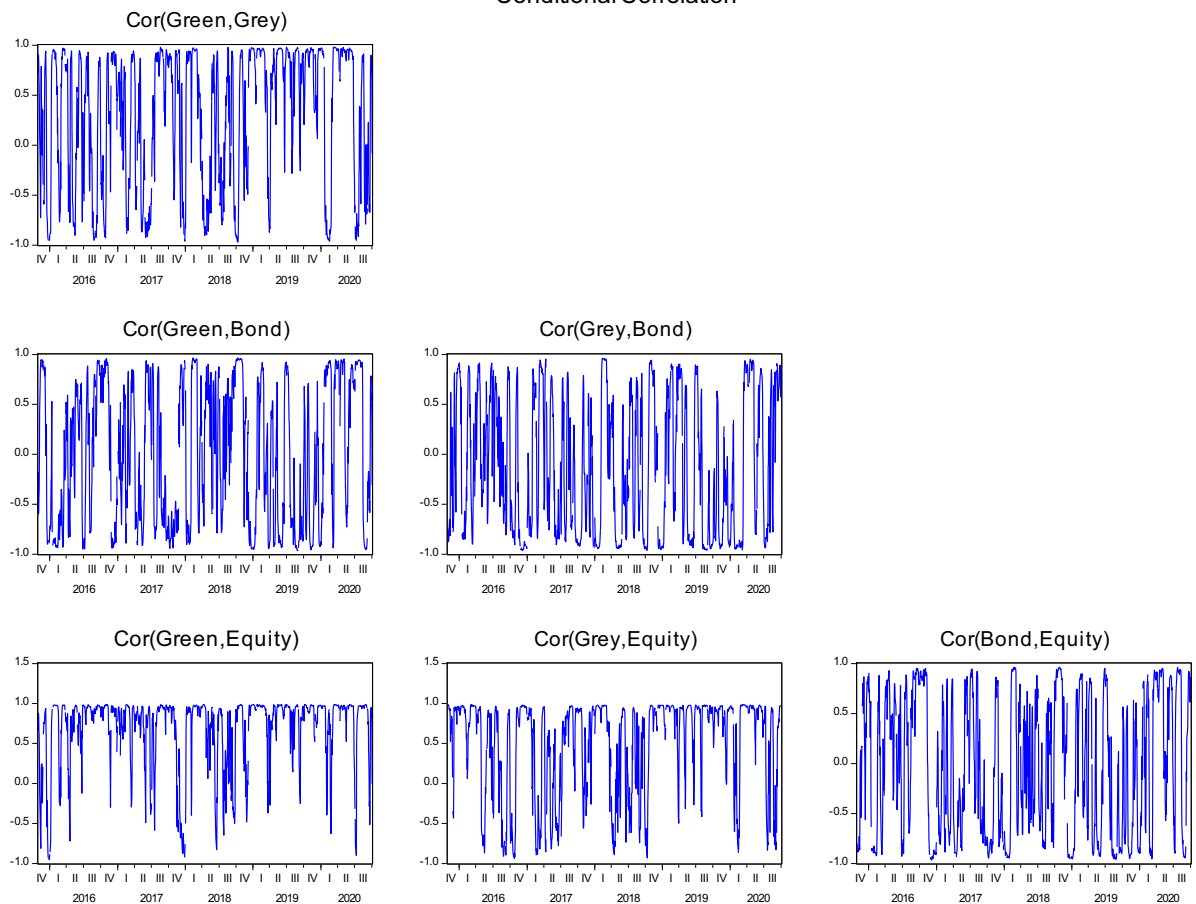

Fig. 6 Conditional correlations based on excess returns (\%) 


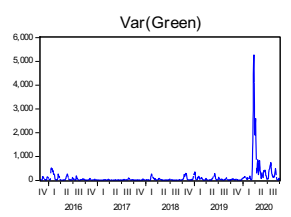

Conditional Variance-Covariance Structures
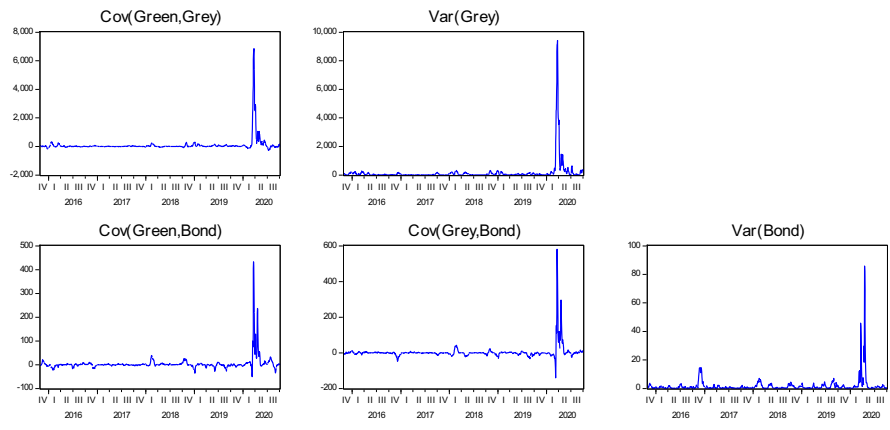

$\operatorname{Cov}$ (Green,Equity)
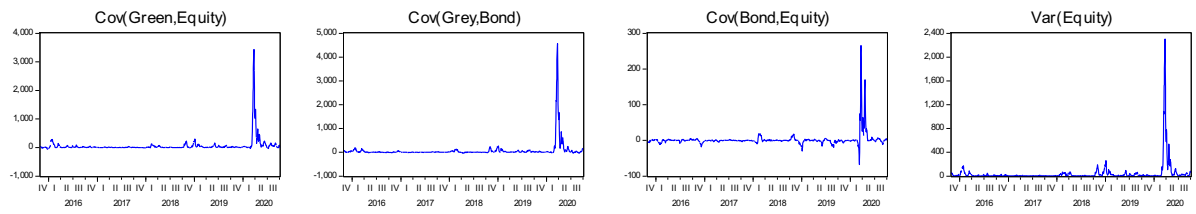

Fig. 7 Conditional variance-covariance structures based on excess returns (\%)

\section{References}

Ahmad, W. (2017). On the dynamic dependence and investment performance of crude oil and clean energy stocks. Research in International Business and Finance, 42, 376-389. https://doi.org/10.1016/j.ribaf. 2017.07.140

Allen, D. E., McAleer, M., Powell, R., \& Singh, A. K. (2017). Volatility spillover and multivariate volatility impulse response analysis of GFC news events. Applied Economics, 49, 3246-3262. https://doi.org/10. 1080/00036846.2016.1257210

Allen, F., \& Gale, D. (2000). Financial contagion. Journal of Political Economy, 108, 1-33. https://doi.org/ $10.1086 / 262109$

Asai, M., Gupta, R., \& McAleer, M. (2020). Forecasting volatility and co-volatility of crude oil and gold futures: Effects of leverage, jumps, spillovers, and geopolitical risks. International Journal of Forecasting, 36(3), 933-948

Batra, A. (2002) Measures for financial stability: Domestic policy requirements for regeneration of international capital flows. Indian Counc. Res. Int. Econ.

Bauwens, L., Laurent, S., \& Rombouts, J. V. K. (2006). Multivariate GARCH models: A survey. Journal of Applied Econometrics, 21, 79-109. https://doi.org/10.1002/jae.842

Bekaert, G., Wu, G., (2000). Asymmetric volatility and risk in equity markets. The review of financial studies

Bernanke, B. S., Gertler, M., \& Watson, M. (1997). Systematic monetary policy and the effects of oil price shocks. Brookings Papers on Economic Activity. https://doi.org/10.2307/2534702

Bernanke, B., Gertler, M., \& Watson, M. W. (2004). Oil shocks and aggregate macroeconomic behavior: The role of monetary policy: A reply. Journal of Money, Credit, and Banking, 36, 28. https://doi.org/10.1353/ mcb.2004.0010

Berndt, E.R., Hall, B.H., Hall, R.E., Hausman, J.A., Berndt, E.R., Hall, B., Hall, R., Hausman, J., (1974). Estimation and Inference in Nonlinear Structural Models 653-665.

Bessler, W., \& Wolff, D. (2015). Do commodities add value in multi-asset portfolios? An out-of-sample analysis for different investment strategies. Journal of Banking and Finance, 60, 1-20. https://doi.org/ 10.1016/j.jbankfin.2015.06.021

Black, F., (1976). \{Stuedies of stock price volatility changes\}, In: Proceedings of the 1976 Meetings of the American Statistical Association, Business and Economics Section. Chicago, pp. 177-181. 
Bollerslev, T., Engle, R.F., Wooldridge, J.M., 1988. A capital asset pricing model with time-varying covariances. Journal of political Economy

Bondia, R., Ghosh, S., \& Kanjilal, K. (2016). International crude oil prices and the stock prices of clean energy and technology companies: Evidence from non-linear cointegration tests with unknown structural breaks. Energy, 101, 558-565. https://doi.org/10.1016/j.energy.2016.02.031

Broadstock, D. C., Cao, H., \& Zhang, D. (2012). Oil shocks and their impact on energy related stocks in China. Energy Econ., 34, 1888-1895. https://doi.org/10.1016/j.eneco.2012.08.008

Brooks, C., \& Persand, G. (2003). Volatility forecasting for risk management. Journal of Forecasting, 22, 1-22. https://doi.org/10.1002/for.841

Broyden, C. G. (1965). A class of methods for solving nonlinear simultaneous equations. Mathematics of Computation, 19, 577-577. https://doi.org/10.1090/s0025-5718-1965-0198670-6

Broyden, C. G. (1967). Quasi-Newton methods and their application to function minimisation. Mathematics of Computation, 21, 368-368. https://doi.org/10.1090/s0025-5718-1967-0224273-2

Campbell, J., Economics, L.H.-J. of financial, (1992) undefined, n.d. No news is good news: An asymmetric model of changing volatility in stock returns. Elsevier.

Caporin, M., \& McAleer, M. (2012). Do we really need both Bekk and Dcc? A tale of two multivariate Garch models. Journal of Economic Surveys, 26(4), 736-751

Chang, C.L., McAleer, M., \& Wang, Y.A., (2018b). Modelling volatility spillovers for bio-ethanol, sugarcane and corn spot and futures prices. Renewable and Sustainable Energy Reviews. https://doi.org/10.1016/j. rser.2017.07.024

Chang, C. L., Li, Y., \& McAleer, M. (2018a). Volatility spillovers between energy and agricultural markets: A critical appraisal of theory and practice. Energies, 11, 1595. https://doi.org/10.3390/en11061595

Chang, C. L., Liu, C. P., \& McAleer, M. (2019a). Volatility spillovers for spot, futures, and ETF prices in agriculture and energy. Energy Econ., 81, 779-792. https://doi.org/10.1016/j.eneco.2019.04.017

Chang, C. L., McAleer, M., \& Tian, J. (2019b). Modeling and testing volatility spillovers in oil and financial markets for the USA, the UK, and China. Energies, 12, 1475. https://doi.org/10.3390/en12081475

Chou, R., (1988). Volatility persistence and stock valuations: Some empirical evidence using GARCH. Journal of Applied Econometrics

Christie, A. A. (1982). The stochastic behavior of common stock variances: Value, leverage and interest rate effects. Journal of Financial Economics, 10, 407-432.

Creti, A., \& Nguyen, D. K. (2015). Energy markets' financialization, risk spillovers, and pricing models. Energy Policy. https://doi.org/10.1016/j.enpol.2015.02.007

Diaz, E. M., Molero, J. C., \& Perez de Gracia, F. (2016). Oil price volatility and stock returns in the G7 economies. Energy Economics, 54, 417-430. https://doi.org/10.1016/j.eneco.2016.01.002

Elsayed, A. H., Nasreen, S., \& Tiwari, A. K. (2020). Time-varying co-movements between energy market and global financial markets: Implication for portfolio diversification and hedging strategies. Energy Econ., 90, 104847. https://doi.org/10.1016/j.eneco.2020.104847

El-Sharif, I., Brown, D., Burton, B., Nixon, B., \& Russell, A. (2005). Evidence on the nature and extent of the relationship between oil prices and equity values in the UK. Energy Economics, 27, 819-830. https:// doi.org/10.1016/j.eneco.2005.09.002

Elyasiani, E., Mansur, I., \& Pagano, M. S. (2007). Convergence and risk-return linkages across financial service firms. Journal of Banking and Finance, 31, 1167-1190.

Engle, R. F., Ito, T., \& Lin, W.-L. (1990). Meteor Showers or Heat Waves? Heteroskedastic intra-daily volatility in the foreign exchange market. Econometrica, 58, 525. https://doi.org/10.2307/2938189

Engle, R. F., Kroner, K. F., Engle, R., \& Kroner, K. F. (1995). Multivariate simultaneous generalized ARCH. Econometric Theory, 11, 122-150.

Ferrer, R., Shahzad, S. J. H., López, R., \& Jareño, F. (2018). Time and frequency dynamics of connectedness between renewable energy stocks and crude oil prices. Energy Economics, 76, 1-20. https://doi.org/10. 1016/j.eneco.2018.09.022

Fletcher, R., \& Powell, M. J. D. (1963). A rapidly convergent descent method for minimization. The Computer Journal, 6, 163-168. https://doi.org/10.1093/comjnl/6.2.163

Franses, P. H., \& Van Dijk, D. (1996). Forecasting stock market volatility using (non-linear) Garch models. Journal of Forecasting, 15, 229-235. https://doi.org/10.1002/(SICI)1099-131X(199604)15:3\%3c229:: AID-FOR620\%3e3.0.CO;2-3

French, K., Schwert, G., Stambaugh, R., (1987). Expected stock returns and volatility. Journal of Financial Economics

Gagnon, M. H., Manseau, G., \& Power, G. J. (2020). They're back! Post-financialization diversification benefits of commodities. International Review of Financial Analysis, 71, 101515. https://doi.org/10.1016/j.irfa. 2020.101515 
Glosten, L. R., Jagannathan, R., \& Runkle, D. E. (1993). On the Relation between the Expected Value and the Volatility of the Nominal Excess Return on Stocks. The Journal of Finance, 48, 1779-1801. https://doi. org/10.2307/2329067

Gokcan, S. (2000). Forecasting volatility of emerging stock markets: Linear versus non-linear GARCH models. Journal of Forecasting, 19, 499-504. https://doi.org/10.1002/1099-131X(200011)19:6\%3c499::AIDFOR745\%3e3.0.CO;2-P

Guesmi, K., \& Fattoum, S. (2014). Return and volatility transmission between oil prices and oil-exporting and oil-importing countries. Economic Modelling, 38, 305-310. https://doi.org/10.1016/j.econmod.2014. 01.022

Gulzar, S., MujtabaKayani, G., Xiaofeng, H., Ayub, U., \& Rafique, A. (2019). Financial cointegration and spillover effect of global financial crisis: A study of emerging Asian financial markets. Economic researchEkonomska Istraživanja, 32, 187-218. https://doi.org/10.1080/1331677X.2018.1550001

Hafner, C. M., \& McAleer, M. (2014). A one line derivation of DCC: Application of a vector random coefficient moving average process. Working Papers in Economics

Hamilton, J. D. (1983). Oil and the macroeconomy since world war II. Journal of Political Economy, 91, 228-248. https://doi.org/10.1086/261140

Hamilton, J. D. (1996). This is what happened to the oil price - Macroeconomy relationship. Journal of Monetary Economics, 38, 215-220. https://doi.org/10.1016/S0304-3932(96)01282-2

Henriksen, T. E. S., Pichler, A., Westgaard, S., \& Frydenberg, S. (2019). Can commodities dominate stock and bond portfolios? Annals of Operations Research, 282, 155-177. https://doi.org/10.1007/s10479-0182996-7

Henriques, I., \& Sadorsky, P. (2008). Oil prices and the stock prices of alternative energy companies. Energy Economics, 30, 998-1010. https://doi.org/10.1016/j.eneco.2007.11.001

Huang, Y., Su, W., Li, X., (2010). Comparison of BEKK GARCH and DCC GARCH models: An empirical study, in: Lecture Notes in Computer Science (Including Subseries Lecture Notes in Artificial Intelligence and Lecture Notes in Bioinformatics). Springer, Berlin, Heidelberg, pp. 99-110. https://doi.org/10.1007/ 978-3-642-17313-4_10

Huang, M. Y., \& Lin, J. B. (2011). Do ETFs provide effective international diversification? Research in International Business and Finance, 25, 335-344. https://doi.org/10.1016/j.ribaf.2011.03.003

IRENA (2020). Global Trends in Renewable Energy Investment 2020.

Kroner, K., studies, V.N.-T. review of financial, (1998) undefined, n.d. Modeling asymmetric comovements of asset returns. academic.oup.com.

Kumar, S., Managi, S., \& Matsuda, A. (2012). Stock prices of clean energy firms, oil and carbon markets: A vector autoregressive analysis. Energy Economics, 34, 215-226. https://doi.org/10.1016/j.eneco.2011. 03.002

Kyritsis, E., \& Serletis, A. (2018). The zero lower bound and market spillovers: Evidence from the G7 and Norway. Research in International Business and Finance, 44, 100-123. https://doi.org/10.1016/J.RIBAF. 2017.05.015

Li, S., (2015). Volatility spillovers in the CSI300 futures and spot markets in China: Empirical study based on discrete wavelet transform and VAR-BEKK-bivariate GARCH model, in: Procedia Computer Science. Elsevier B.V., pp. 380-387. https://doi.org/10.1016/j.procs.2015.07.085

Li, J.-P., Naqvi, B., Rizvi, S. K. A., \& Chang, H.-L. (2021). Bitcoin: The biggest financial innovation of fourth industrial revolution and a portfolio's efficiency booster. Technol. Forecast. Soc. Change, 162, 120383. https://doi.org/10.1016/j.techfore.2020.120383

Maghyereh, A. I., Awartani, B., \& Abdoh, H. (2019). The co-movement between oil and clean energy stocks: A wavelet-based analysis of horizon associations. Energy, 169, 895-913. https://doi.org/10.1016/j.energy. 2018.12.039

Maghyereh, A. I., Awartani, B., \& Bouri, E. (2016). The directional volatility connectedness between crude oil and equity markets: New evidence from implied volatility indexes. Energy Economics, 57, 78-93. https://doi.org/10.1016/j.eneco.2016.04.010

Managi, S., \& Okimoto, T. (2013). Does the price of oil interact with clean energy prices in the stock market? Japan World Economics, 27, 1-9. https://doi.org/10.1016/j.japwor.2013.03.003

Mensi, W., Beljid, M., Boubaker, A., \& Managi, S. (2013). Correlations and volatility spillovers across commodity and stock markets: Linking energies, food, and gold. Economic Modelling, 32, 15-22. https:// doi.org/10.1016/j.econmod.2013.01.023

Miralles-Quirós, J. L., \& Miralles-Quirós, M. M. (2019). Are alternative energies a real alternative for investors? Energy Economics, 78, 535-545. https://doi.org/10.1016/j.eneco.2018.12.008

Miralles-Quirós, J. L., Miralles-Quirós, M. M., \& Nogueira, J. M. (2018). Diversification benefits of using exchange-traded funds in compliance to the sustainable development goals. Business Strategy and the Environment, 28, 244-255. https://doi.org/10.1002/bse.2253 
Mirza, N., Rahat, B., Naqvi, B., \& Rizvi, S. K. A. (2020). Impact of Covid-19 on corporate solvency and possible policy responses in the EU. The Quarterly Review of Economics and Finance. https://doi.org/ 10.1016/j.qref.2020.09.002

Naqvi, B., Rizvi, S. K. A., Mirza, N., \& Reddy, K. (2018). Religion based investing and illusion of Islamic Alpha and Beta. Pacific Basin Finance Journal, 52, 82-106. https://doi.org/10.1016/j.pacfin.2018.02.003

Nguyen, M. K., \& Le, D. N. (2021). Return Spillover from the US and Japanese stock markets to the vietnamese stock market: A frequency-domain approach. Emerging Markets Finance and Trade, 57, 47-58. https:// doi.org/10.1080/1540496X.2018.1525357

Park, J., \& Ratti, R. A. (2008). Oil price shocks and stock markets in the U.S. and 13 European countries. Energy Economics, 30, 2587-2608. https://doi.org/10.1016/j.eneco.2008.04.003

Reboredo, J. C., Rivera-Castro, M. A., \& Ugolini, A. (2017). Wavelet-based test of co-movement and causality between oil and renewable energy stock prices. Energy Econ., 61, 241-252. https://doi.org/10.1016/j. eneco.2016.10.015

Reboredo, J. C., \& Ugolini, A. (2018). The impact of energy prices on clean energy stock prices. A multivariate quantile dependence approach. Energy Economics, 76, 136-152. https://doi.org/10.1016/j.eneco.2018. 10.012

Rehman, M. U., Bouri, E., Eraslan, V., \& Kumar, S. (2019). Energy and non-energy commodities: An asymmetric approach towards portfolio diversification in the commodity market. Resources Policy, 63, 101456. https://doi.org/10.1016/j.resourpol.2019.101456

Rehman, M. U., \& Vo, X. V. (2020). Do alternative energy markets provide optimal alternative investment opportunities? North Am. J. Econ. Financ., 54, 101271. https://doi.org/10.1016/j.najef.2020.101271

Rezec, M., \& Scholtens, B. (2017). Financing energy transformation: The role of renewable energy equity indices. International Journal of Green Energy, 14, 368-378. https://doi.org/10.1080/15435075.2016. 1261704

Rizvi, S. K. A., Itani, R., (2021). Oil market volatility: Comparison of COVID-19 crisis with the SARS outbreak of 2002 and the global financial crisis of 2008. Economic Research-Ekonomska Istraživanja. https://doi.org/10.1080/1331677X.2021.1927788

Rizvi, S. K., \& Naqvi, B. (2008). Asymmetric behavior of inflation uncertainty and friedman-ball hypothesis: Evidence from Pakistan. Lahore Journal of Econ., 2, 1-33.

Rizvi, S. K. A., Naqvi, B., \& Bordes, C. (2013). Time varying equity market beta as an index of financial openness? Applied Financial Economics. https://doi.org/10.1080/09603107.2013.778946

Rizvi, S. K., Naqvi, B., Bordes, C., \& Mirza, N. (2014). Inflation volatility: An Asian perspective. Economic Research-Ekonomska Istraživanja, 27, 280-303. https://doi.org/10.1080/1331677X.2014.952090

Sadorsky, P. (1999). Oil price shocks and stock market activity. Energy Economics, 21, 449-469. https://doi. org/10.1016/S0140-9883(99)00020-1

Sadorsky, P. (2012). Correlations and volatility spillovers between oil prices and the stock prices of clean energy and technology companies. Energy Economics, 34, 248-255. https://doi.org/10.1016/j.eneco. 2011.03.006

Sadorsky, P. (2014). Modeling volatility and correlations between emerging market stock prices and the prices of copper, oil and wheat. Energy Economics, 43, 72-81. https://doi.org/10.1016/j.eneco.2014.02.014

Saeed, T., Bouri, E., \& Tran, D. K. (2020). Hedging strategies of green assets against dirty energy assets. Energies, 13, 3141. https://doi.org/10.3390/en13123141

Sarwar, S., Shahbaz, M., Anwar, A., \& Tiwari, A. K. (2019). The importance of oil assets for portfolio optimization: The analysis of firm level stocks. Energy Economics, 78, 217-234. https://doi.org/10. 1016/j.eneco.2018.11.021

Sarwar, S., Tiwari, A. K., \& Tingqiu, C. (2020). Analyzing volatility spillovers between oil market and Asian stock markets. Resources Policy, 66, 101608. https://doi.org/10.1016/j.resourpol.2020.101608

Schmidt, A. B. (2019). Managing portfolio diversity within the mean variance theory. Annals of Operations Research, 282, 315-329. https://doi.org/10.1007/s10479-018-2896-x

Scott, H., (2011). How to Improve Five Important Areas of Financial Regulation. Rules Growth Promot. Innov. Growth.

Song, H., Liu, X., Romilly, P., (1998). Stock returns and volatility: An empirical study of Chinese stock markets. Int. Rev. Appl.

Su, C. W., Naqvi, B., Shao, X. F., Li, J. P., \& Jiao, Z. (2020). Trade and technological innovation: The catalysts for climate change and way forward for COP21. Journal of Environmental Management, 269, 110774. https://doi.org/10.1016/j.jenvman.2020.110774

Theodossiou, P., Kahya, E., Koutmos, G., (1997). Volatility reversion and correlation structure of returns in major international stock markets. Financial.

Tiwari, A.K., Nasreen, S., Ullah, S., Shahbaz, M., (2020). Analysing spillover between returns and volatility series of oil across major stock markets. International Journal of Finance and Economics. 
Umar, M., Rizvi, S. K. A., \& Naqvi, B. (2020). Dance with the devil? The nexus of fourth industrial revolution, technological financial products and volatility spillovers in global financial system. Technological Forecasting and Social ChangeTechnol. https://doi.org/10.1016/j.techfore.2020.120450

Wang, G., Tang, Y., Xie, C., \& Chen, S. (2019). Is bitcoin a safe haven or a hedging asset? Evidence from China. Journal of Management Science and Engineering, 4, 173-188. https://doi.org/10.1016/j.jmse. 2019.09.001

Wen, X., Guo, Y., Wei, Y., \& Huang, D. (2014). How do the stock prices of new energy and fossil fuel companies correlate? Evidence from China. Energy Economics, 41, 63-75. https://doi.org/10.1016/j. eneco.2013.10.018

Yan, L., \& Garcia, P. (2017). Portfolio investment: Are commodities useful? Journal of Commodity Markets, 8, 43-55. https://doi.org/10.1016/j.jcomm.2017.10.002

Yousaf, I., Ali, S., Bouri, E., Saeed, T., (2021). Information transmission and hedging effectiveness for the pairs crude oil-gold and crude oil-Bitcoin during the COVID-19 outbreak. Economic Research-Ekonomska Istraživanja. https://doi.org/10.1080/1331677X.2021.1927787

Zhang, D. (2017). Oil shocks and stock markets revisited: Measuring connectedness from a global perspective. Energy Economics, 62, 323-333. https://doi.org/10.1016/j.eneco.2017.01.009

Publisher's Note Springer Nature remains neutral with regard to jurisdictional claims in published maps and institutional affiliations. 